AperTO - Archivio Istituzionale Open Access dell'Università di Torino

\title{
Post-collisional tectonics in the Northern Cottian Alps (Italian Western Alps)
}

\section{This is the author's manuscript}

Original Citation:

Availability:

This version is available http://hdl.handle.net/2318/78230

since 2015-12-23T10:55:51Z

Published version:

DOI:10.1007/s00531-010-0534-1

Terms of use:

Open Access

Anyone can freely access the full text of works made available as "Open Access". Works made available under a Creative Commons license can be used according to the terms and conditions of said license. Use of all other works requires consent of the right holder (author or publisher) if not exempted from copyright protection by the applicable law. 


\section{(5) \\ UNIVERSITÀ DEGLI STUDI DI TORINO}

This is an author version of the contribution published on:

Questa è la versione dell'autore dell'opera:

Post-collisional tectonics in the Northern Cottian Alps (Italian Western Alps)

International Journal of Earth Sciences

September 2011, Volume 100, Issue 6, pp 1349-1373

DOI: $\underline{10.1016 / j . j o g .2013 .02 .004}$

The definitive version is available at:

La versione definitiva è disponibile alla URL:

http://link.springer.com/article/10.1007\%2Fs00531-010-0534-1 
Post-collisional tectonics in the Northern Cottian Alps (Italian Western Alps)

G. Perrone, P. Cadoppi, S. Tallone and G. Balestro

\begin{abstract}
Field mapping and structural analysis have allowed us to characterise the fault geometry and the postmetamorphic tectonics of an area located in the Northern Cottian Alps (inner Western Alps). Two main faulting stages were distinguished here. The first (Oligocene?-Early Miocene) is related to the development of an E-W-striking left-normal shear zone. This shear zone is interpreted as an antithetical of two regional, $\mathrm{N}-\mathrm{S}$ right-lateral structures: the Col del Lis-Trana Deformation Zone (LTZ) and the Colle delle Finestre Deformation Zone (CFZ). The second faulting stage (post-Early Miocene) is related mainly to the development of $\mathrm{N}-\mathrm{S}$ normal faults, coeval with the extensional reactivation of the LTZ and the CFZ. We discuss this kinematic evolution in the framework of the geodynamic evolution of the Western Alps.

\section{Introduction}

The arc of the Western Alps (Fig. 1) resulted from the convergence and subsequent collision between the Adria plate and the European margin of the Tethys since the Late Cretaceous (Ricou and Siddans 1986; Laubscher 1991; Steck and Hunziker 1994; Schmid et al. 2004 and references therein).
\end{abstract}



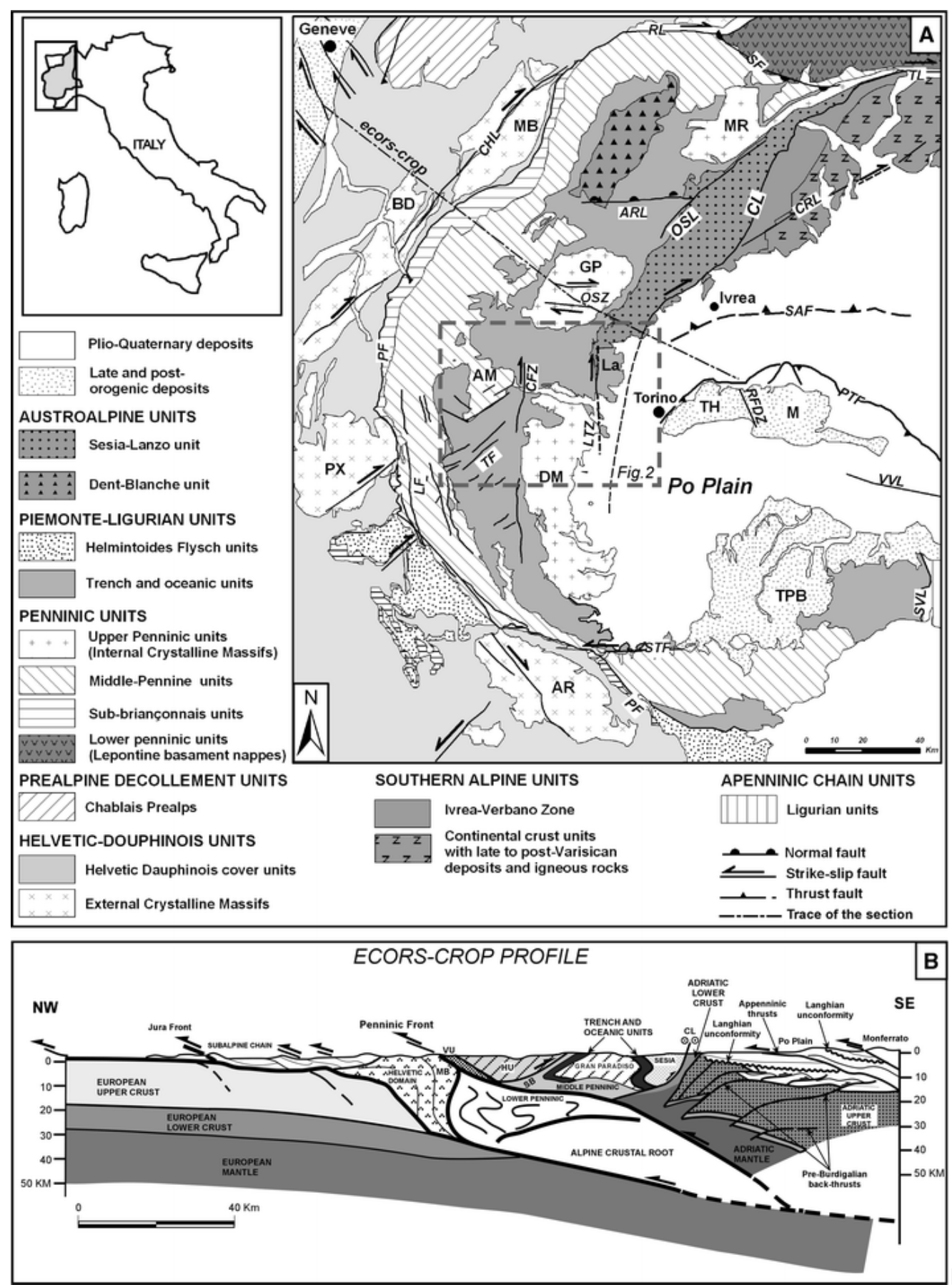

Fig. 1

a Tectonic sketch map of Western Alps. The dashed grey rectangle indicates the area shown in Fig. 2. AM Ambin Unit, AR Argentera Massif, BD Belledonne Massif, DM Dora-Maira Unit, GP Gran Paradiso Unit, La Lanzo ultramafic complex, M Monferrato, MB Mont Blanc Massif, MR Monte-Rosa Unit, PX Pelvoux Massif, TH Torino Hill, TPB Tertiary Piemonte Basin, ARL Aosta-Ranzola Line, CFZ Colle delle Finestre Deformation Zone, CHL Chamonix Line, CL Canavese Line, CRL Cremosina Line, LF Longitudinal fault system, LTZ Col del Lis-Trana Deformation Zone, OSL Ospizio-Sottile Line, OSZ Orco Shear Zone, PF Penninic Front, PTF Padan Thrust Front, RFDZ Rio Freddo Deformation Zone, RL Rodano Line, SAF Southern Alpine Thrust, SF Simplon Fault, STF Stura Fault, SVL SestriVoltaggio Line, TL Tonale Line, VVL Villavernia-Varzi Line. After Bigi et al. (1990), Bistacchi and Massironi (2000), Piana (2000) and Perello et al. (2004a, b). b Crustal-scale interpretation of the ECORS-CROP (trace of the section in a). CL Canavese Line, HU Houiller Unit, MB Mont-Blanc Unit, VU Valaisan Unit, SB Gran St. Bernard nappe. After Roure et al. (1990)

The early tectonic Alpine history (Late Cretaceous-Paleocene) is related to the subduction of the oceanic crust, with the juxtaposition of nappes under high to very high-pressure metamorphic conditions (Coward and Dietrich 1989; Polino et al. 1990; Schmid and Kissling 2000). 
The continental collision (Late Eocene-Early Oligocene) is responsible for the fore-thrusting towards the external domain (Schmid and Kissling 2000), and the eastward back-thrusting, in the internal domain (Tricart 1984; Debelmas 1986; Platt et al. 1989; Tricart and Sue 2006), occurred mostly under greenschist facies metamorphic conditions.

Starting from the late Oligocene, the post-collisional tectonics induced dextral strike-slip faulting in the most internal sectors of the chain, along the Canavese Line (CL in Fig. 1; Schmid et al. 1987), and in the external sectors, along the Chamonix Line and Rhone Line (CHL and RL in Fig. 1; Gourlay and Ricou 1983; Hubbard and Mancktelow 1992). Also within the Argentera Massif, some regional NW-SE striking faults show right-lateral movements (Perello et al. 2001; Baietto et al. 2009). By contrast, in the Jura Mountains, a NW-vergent fold and thrust belt developed since the Miocene (Mugnier and Vialon 1986). In the inner part of the chain, bordered by the Penninic Frontal Thrust and the Canavese Line, a number of papers (Cannic et al. 1999; Bistacchi et al. 2000; Rolland et al. 2000; Collombet et al. 2002; Calais et al. 2002; Agard et al. 2003; Sue and Tricart 1999, 2002, 2003; Delacou et al. 2004, 2008; Champagnac et al. 2004, 2006; Selverstone, 2005; Tricart et al. 2001, 2004, 2007; Sue et al. 2007a; Schwartz et al. 2008) based on structural, fission track, paleomagnetic, seismological and geodetic data showed an extensionaltranstensive regime at least since the Miocene. In the central part of the Western Alps, two regional brittle fault systems, the Longitudinal and Transversal Fault systems (LF and TF in Fig. 1, Sue and Tricart 2002, 2003; Tricart and Sue 2006), accommodated this regime, which also caused the inversion of the Penninic Frontal Thrust (Sue and Tricart 1999), the westward tilting of the nappe pile of the Piemonte Zone (Tricart et al. 2004; Schwartz et al. 2008) and the doming of the Dora-Maira Unit (Philippot 1990; Ballèvre et al. 1990). In the northern sector of the chain, E-W transtensive faults (OSZ in Fig. 1) were described by Perello et al. (2004b), whereas Bistacchi et al. (2000) found an extensional regime with a dominant stretching direction parallel to the belt, mostly related to the activity of the Simplon (SF in Fig. 1) and Aosta-Ranzola (ARL in Fig. 1) faults. Champagnac et al. $(2004,2006)$, on the basis of the paleostress analysis of several meso-structural data, showed a more complex post-collisional tectonic evolution for this sector characterised by the occurrence of a further extension direction, roughly perpendicular to the trend of the belt, that follows the orogen-parallel extension.

Different models have been proposed to explain this complex structural setting, such as westward extrusion (Coward and Dietrich 1989), dextral transcurrence at the scale of the chain induced by the counterclockwise rotation of the Adria plate since Oligocene (Vanossi et al. 1994; Castellarin 2001; Collombet et al. 2002; Agard et al. 2003; Sue and Tricart 2003; Malusà et al. 2005, 2009), and polyphasic models that associate south-westward extrusion (Sue et al. 2007a; Champagnac et al. 2004, 2006) or dextral transcurrence (Delacou et al. 2004; Perello et al. 2004b) with buoyancy forces.

In this work field mapping, detailed structural and morphostructural analyses (Perrone 2006) were integrated with the aim to outline the fault geometry and the post-metamorphic kinematic evolution of an area located in the inner Western Alps (Northern Cottian Alps, see Fig. 2). The results of this study have been integrated with the investigations carried out in the adjacent areas, in the framework of the CARG project (Bardonecchia, Susa and Torino Ovest sheets of the geological map of Italy at a scale of 1:50,000; Polino et al. 2002; Carraro et al. 2002; Balestro et al. 2009b) and in the context of the feasibility study for the Turin-Lyon railway connection (Sacchi et al. 2004; Perello et al. 2004a), in order to outline the postcollisional tectonic evolution of the Northern Cottian Alps. These new data may represent a further constraint for the kinematic model of the internal Western Alps and give a better insight into the mechanisms that drove its tectonic evolution by Late Oligocene times. 


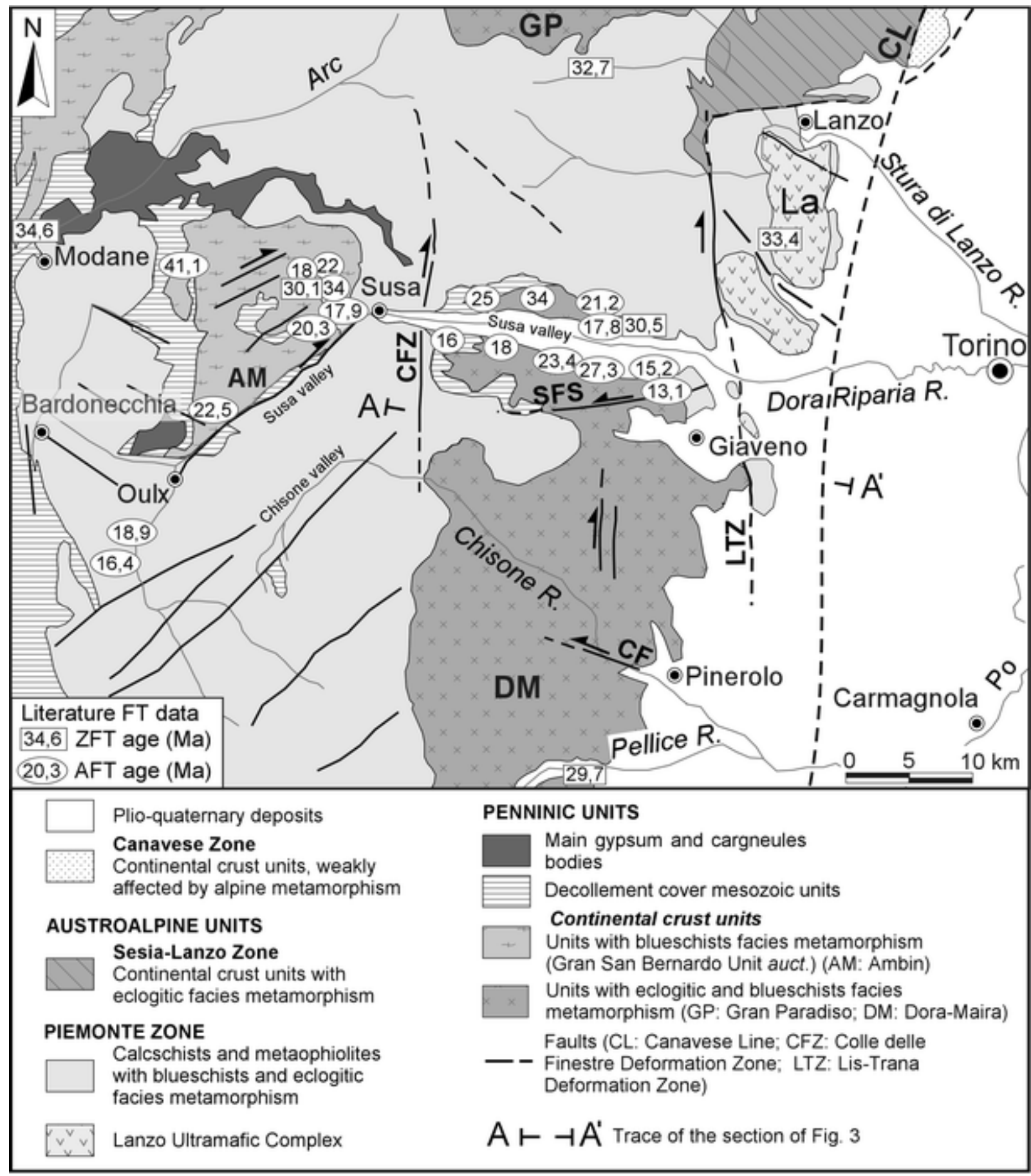

Fig. 2

Structural setting of the Northern Cottian Alps (after Cadoppi et al. 2007) with published thermo-chronological data. Zircon fission track (FT) data from Bernet et al. (2001); Apatite FT data from Cadoppi et al. (2002a), Balestrieri et al. (2004), Malusà et al. (2005), Tricart et al. (2007) and Schwartz et al. (2008)

\section{Regional fault systems of the inner Central-Western Alps}

Two major first-order lithospheric discontinuities bound the inner part of the Western Alps: the Penninic Frontal Thrust (PF) and the Canavese Line (CL) (Fig. 1). 
PF separates the alpine HP/LT metamorphic units from the underlying low-grade metamorphic units. Its main activity occurred in the Early Oligocene (Tricart 1984); since the Miocene times the PF underwent an extensional reactivation (Tricart et al. 2001).

$\mathrm{CL}$ represents the boundary between the alpine metamorphic units and the retroforeland verging fold and thrust belt of the Southern Alps. This is described as a steep dextral-reverse fault that was active mainly during the Oligocene-Miocene (Schmid et al. 1987, 1989); its continuity in the South-Western Alps, at present masked by the deposits of the Po Plain, and its persistence at depth has been inferred through the interpretation of different seismic, gravimetric and magnetic investigations (Lanza 1975; Ménard and Thouvenot 1984; Nicolas et al. 1990; Béthoux et al. 2007; Mosca et al. 2009).

Other regional fault systems in the central part of the inner Western Alps were recently described. These structures may be considered minor faults of the $\mathrm{CL}$ and $\mathrm{PF}$ and correspond to:

- Col del Lis-Trana Deformation Zone (LTZ in Figs. 1a, 2, 3), extending for about $30 \mathrm{~km}$ from the Lower Susa Valley to the Lower Sangone Valley. The LTZ is characterised by N-S major faults and by NNW-SSE and NNE-SSW minor faults, linked in a through-going shear zone with dextral shearing and a minor reversal component. At regional scale, the dextral component of movement is expressed by the clockwise rotation of the pre-existing syn-metamorphic structures (foliations, lithological and tectonic contacts) from an $\mathrm{E}-\mathrm{W}$ to a $\mathrm{N}-\mathrm{S}$ direction (Balestro et al. 2007, 2009a) approaching the LTZ. Subsequently, this structure underwent an extensional reactivation outlined both by the overprinting of different striae generations and by the crosscutting relations among transcurrent and normal faults. Since the LTZ seems to be a persistent and deep-rooted structure, it is interpreted as a minor sub-parallel fault strand of the postulated southern prolongation of the CL (Fig. 3; Balestro et al. 2009a).

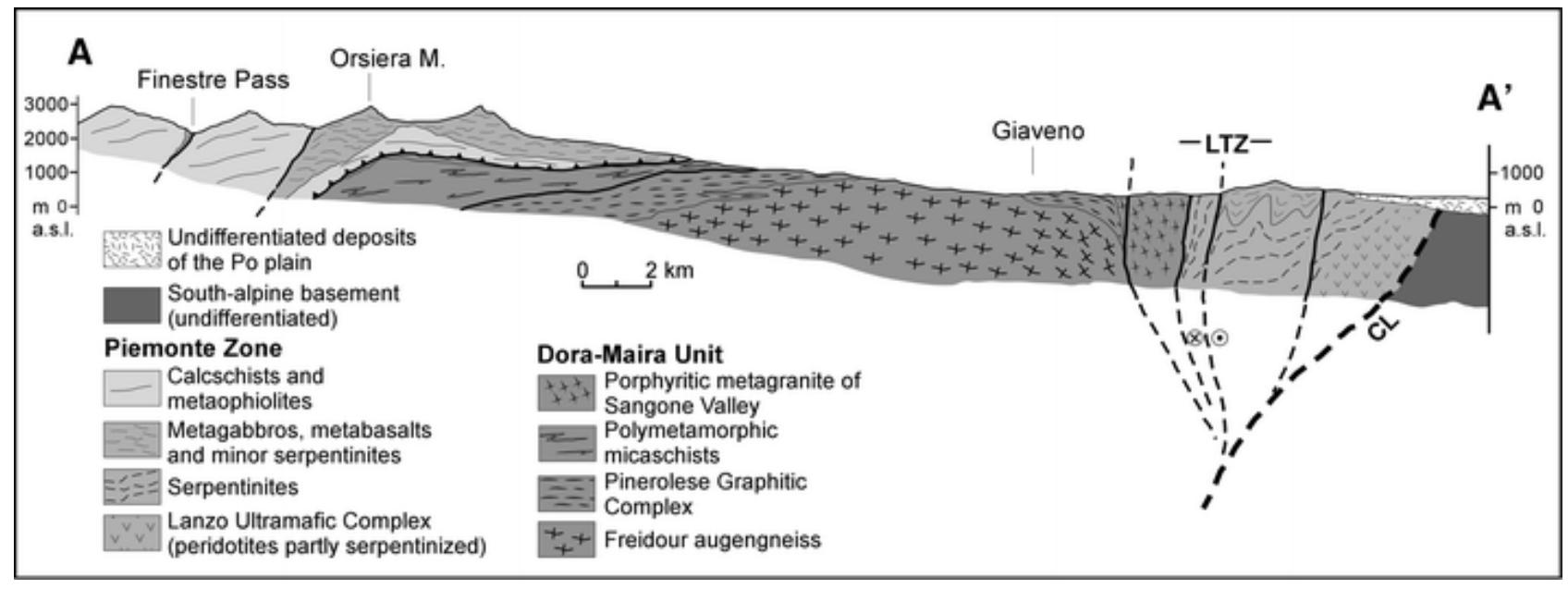

Fig. 3

Geological section across the innermost Cottian Alps. Trace of section in Fig. 2

- Colle delle Finestre Deformation Zone (CFZ in Figs. 1a, 2; Carraro et al. 2002). This structure runs from the Lower Susa Valley to the Middle Chisone Valley, juxtaposing in its southern termination different units of an oceanic setting (Cadoppi et al. 2002b). The kinematics of the CFZ has evolved from right-lateral to normal (Tallone et al. 2002; Cadoppi et al. 2007). Pleistocene to Holocene 
deposits displaced by mesoscale normal faults (Carraro et al. 2002; Giardino and Polino 1997; Polino et al. 2002) and neotectonic landforms suggest that their late extensional activity was protracted until the Quaternary (Cadoppi et al. 2007);

- Longitudinal Fault system (Fig. 1a; Sue and Tricart 2002, 2003). These N-S to NW-SE multikilometric steep normal faults displace the Briançonnais Zone units. The LF was reactivated with right-lateral movements during the Pliocene times (Sue and Tricart 2003).

- Transverse Fault system (Fig. 1a; Sue and Tricart 2002, 2003), corresponding to NE-SW and E-W faults developed mainly in the Piemonte Zone. East of Briançon these structures are described as normal faults, some of which show evidence of left-lateral reactivation (Sue and Tricart 2003). In the Middle Susa and Chisone Valleys (Figs. 1a, 2), they are described as right-lateral faults (Perello et al. 2004a; Malusà 2004) reactivated, in the Pleistocene times, by normal-sinistral movements (Giardino and Polino 1997).

\section{Geological setting of the Northern Cottian Alps}

In the Northern Cottian Alps, different continental margin, oceanic and trench units of the Penninic Domain (Figs. 2, 3) are exposed. The deepest of this unit, stacked during the syn-metamorphic tectonic phases, is represented by the Dora-Maira Unit (DM). The DM is a continental crust unit characterised by a preMesozoic basement, mainly composed of poly- and mono-metamorphic metapelites intruded by metaintrusives related to the late Variscan magmatic event. A Mesozoic metasedimentary complex made of dolomitic marbles and calcschists rests on this basement.

In the mapped area (Fig. 4), the DM is represented by three superposed basement complexes composed of metagranites, metadiorites and metasediments (that include polymetamorphic garnet-chloritoid micaschists, Carboniferous graphite schists and paragneisses) bounded by syn-metamorphic ductile contacts (Cadoppi and Tallone 1992; Sandrone et al. 1993; Bussy and Cadoppi 1996). 


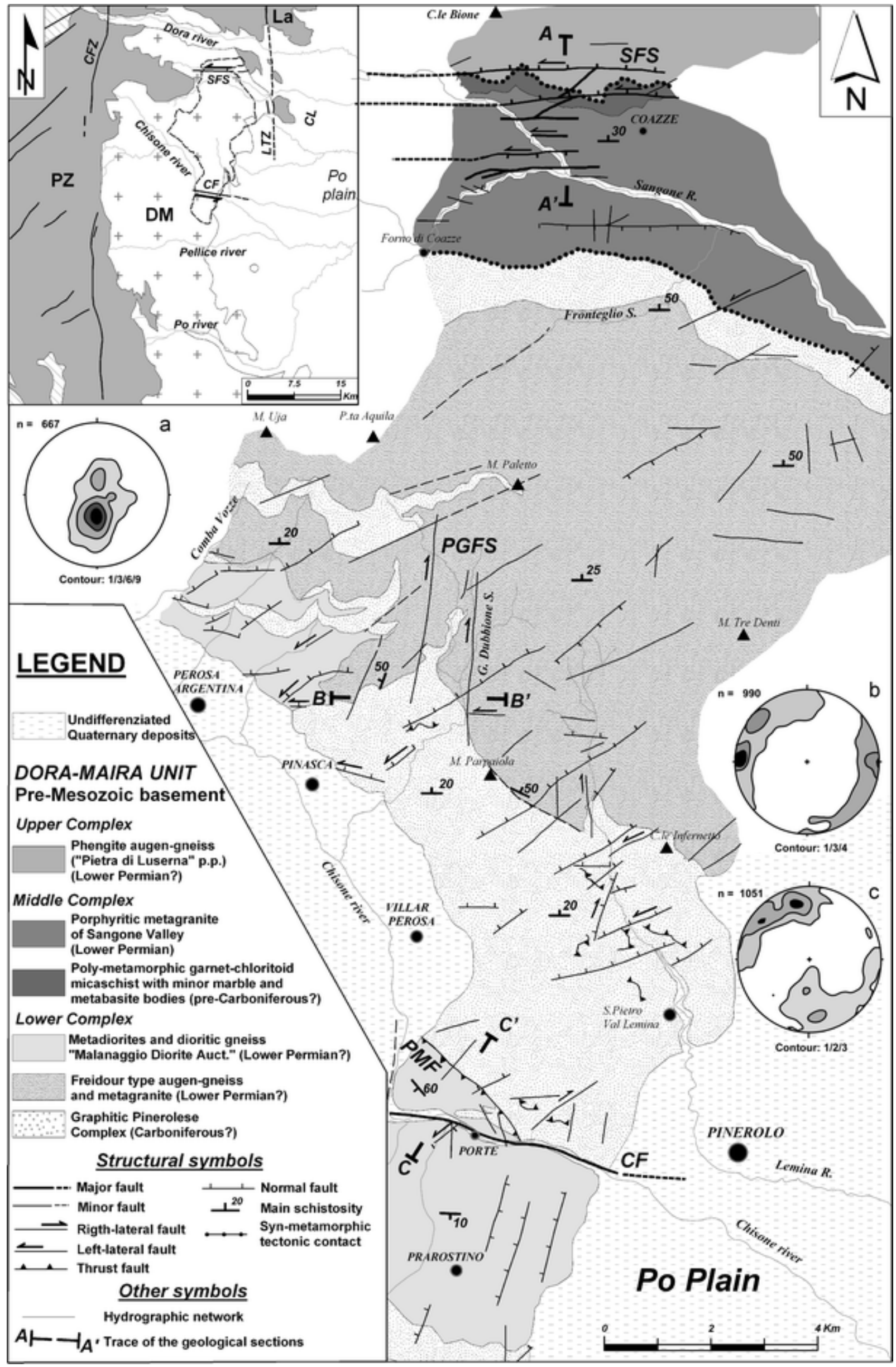


Fig. 4

Geological-structural map of the study area, with Schmidt equal-area projections (lower hemisphere) showing the mesoscopic data collected in the entire study area relative to (a) ST foliation, (b) total faults and (c) fractures. The inset shows the location of the study area (keys as in Fig. 1a), and the heavy dashed lines indicate the limits of the mapped area. CF Chisone Fault, CFZ Colle delle Finestre Deformation Zone, CL Canavese Line, LTZ Col del Lis-Trana Deformation Zone, PGFS Pinasca-Gran Dubbione fault system, PMF Porte-Malanaggio Fault, SFS Sangone fault system. Modified from Perrone et al. (2009a)

The DM is overthrusted by units belonging to the Piemonte Zone, consisting of metaophiolites, which represent slices of the Mesozoic Ligurian-Piemontese Ocean and metasediments that probably are the remnants of converging foredeep deposits (Pognante 1980; Lemoine and Tricart 1986). Well-preserved peridotites that mostly escaped Alpine metamorphism, belonging to the Lanzo ultramafic complex, are interpreted as a slice of lithospheric mantle (Elter et al. 2005 and reference therein).

All these units shared the same Alpine tectono-metamorphic evolution. The two earlier deformation phases (D1 and D2 phases; Pognante and Sandrone 1989), coeval with high-pressure metamorphism (Eoalpine event), caused the stacking of the main units and the development of large-scale isoclinal folding. Regional re-equilibration in greenschist facies (Mesoalpine event) is coeval with the subsequent D3 deformation phase characterised by regional south-verging folds (Cadoppi and Tallone 1992). The late-metamorphic tectonic evolution is consistent with roughly $\mathrm{N}-\mathrm{S}$-trending open to gentle fold system ascribed to the $\mathrm{D} 4$ phase (Cadoppi et al. 2002b), widespread mainly at all scales in the metasedimentary units of the Susa Valley.

Fission track data (Fig. 2) indicate that since Oligocene this sector of Western Alps reached shallow crustal levels, where metamorphic processes are absent, and a complex fault network developed.

\section{Structural analysis}

The analysis of post-metamorphic discontinuous deformations has been carried out by field mapping (1:25.000 scale, Fig. 4) as well as detailed meso-structural analysis of brittle shear zones. The fault network affecting the study area has been compared with the pattern of the lineaments detected by multi-scale photo-interpretation (by means of Landsat7 and aerial images) to obtain a better insight into the geometry and hierarchy of the observed structures (Fig. 5; see also Perrone et al. 2009a for a more detailed discussion). This integrated approach allowed us to distinguish different structural domains with distinctive fault patterns and to locate the traces of inferred faults that separate sectors with different internal fault geometries. The interpretation of the data is based on the definition of distinct structural associations (sensu Hobbs et al. 1976) which represent different tectonic stages recorded during the post-metamorphic tectonic evolution. As proposed by some authors (Dehandschutter 2001; Rossetti et al. 2002; Perello et al. 2004b), the structural characterisation of faults in the field was carried out on the basis of 


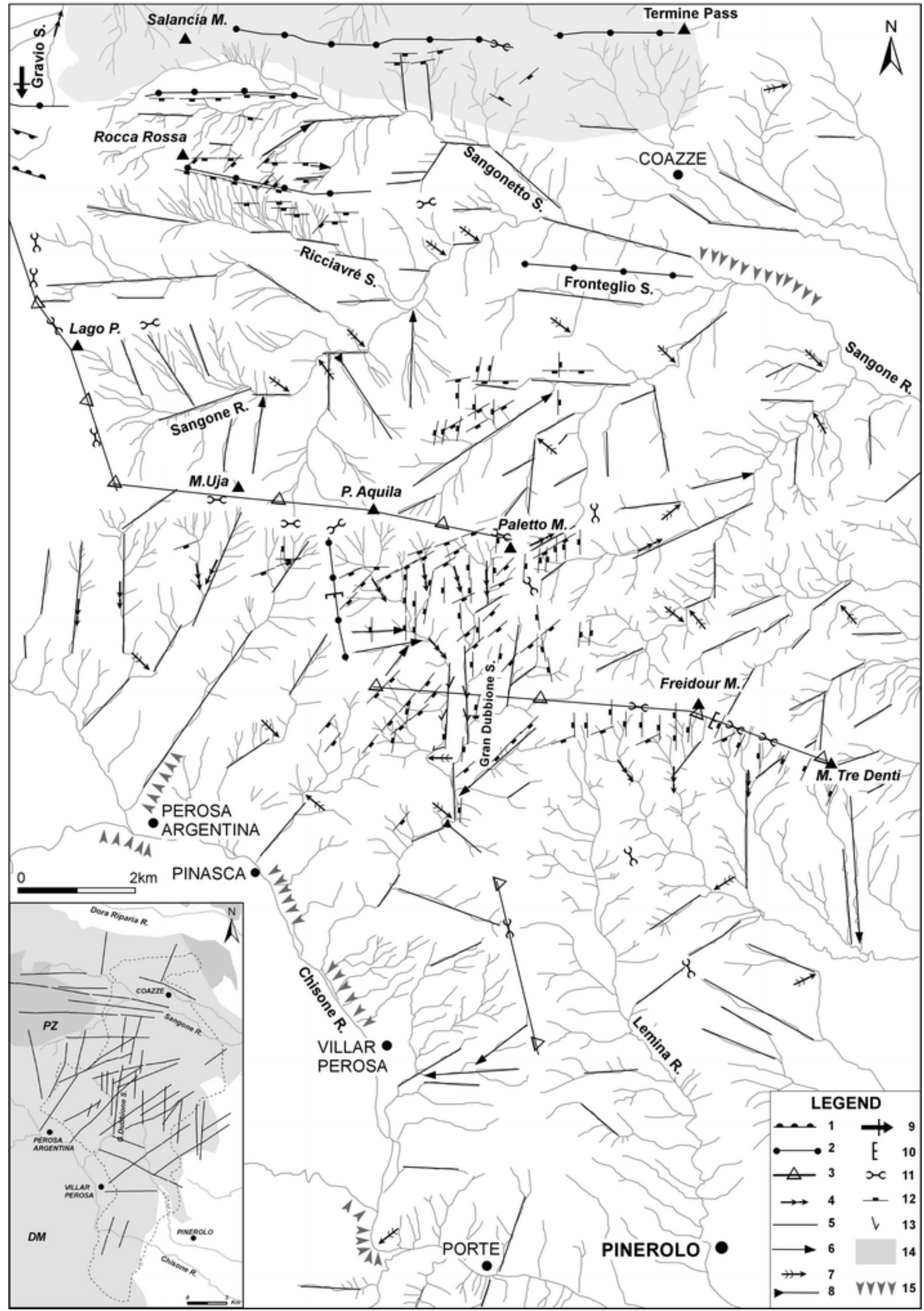

Fig. 5 
a map of the morphotectonic elements of the study area. (1) double ridge, (2) linear ridge, (3) peaks alignment, (4) deep fluvial incision, (5) straight fluvial incision, (6) straight valley, (7) fluvial diversion, (8) upstream confluence, (9) new born valley head, (10) altimetric discontinuity along ridge, (11) wind gap and pass, (12) major scarps, (13) asymmetric valley (14) deep seated gravitational slope deformation, (15) main fluvial terraces. $b$ Interpreted lineaments map in the study area. DM Dora-Maira Unit, PZ Piemonte Zone

- geometry;

- analysis of kinematic indicators and distribution of slip vectors;

- rheology and thickness of fault-related rocks;

- mineralogy of slickenfibres on fault surfaces.

Major and minor faults also were differentiated on the basis of their length and the width of the damage zone.

Because Neogene geological and stratigraphic markers that allow chronological constraints on the activity of the post-metamorphic structures are lacking, the relative ages of faults are based on their cross-cutting relations and on the nature of the fault rocks.

In the following paragraphs, the hierarchy, geometry and kinematics of the different fault systems are first analysed, and then the paleostrain analysis of fault-slip data is discussed in order to deduce the orientation of the principal strain axes in the study area.

Following Angelier (1994), in this paper, we use the term 'fault' to refer to a single fault segment and 'fault system' to arrays of roughly contemporaneous faults. Moreover, under the general term of 'deformation zone', we refer to a regional, highly strained domain of multi-kilometre length and kilometre-scale-thick damage zone, which underwent poly-phase kinematic activity.

\section{Geometrical analysis of the fault pattern}

Four main fault systems are developed with average strikes E-W, NE-SW, N-S and NW-SE (Fig. 4). Slickenlines show strike-slip and dip-slip movements (Fig. 6). 


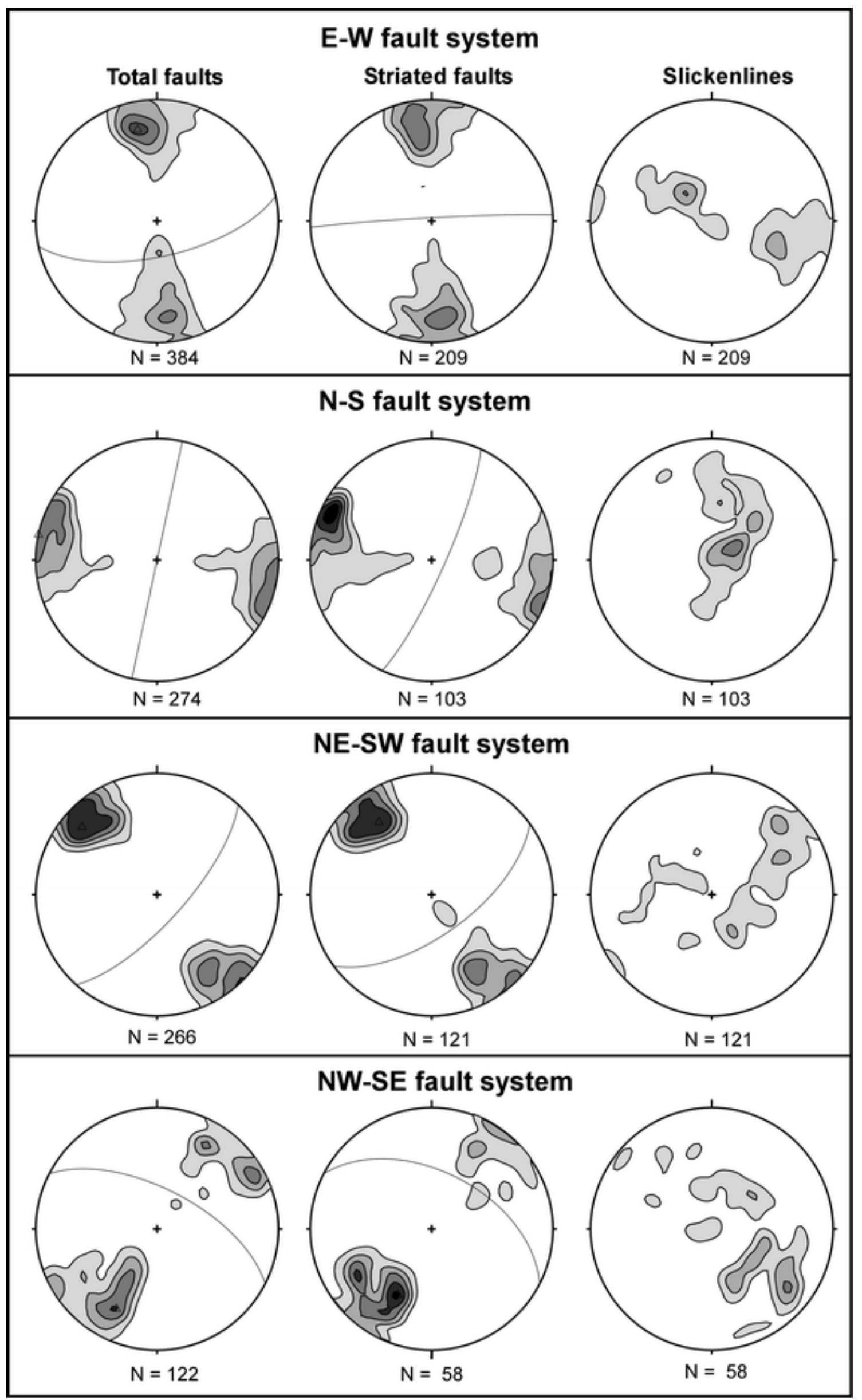


Fig. 6

Contoured stereoplots (equal-area, lower hemisphere projections) relative to the brittle structural data collected in the mapped area. The great circles show the mean fault plane orientations of the different fault systems. Data contoured at $n=2,4,6,8,10$ times uniform

The major post-metamorphic features correspond to two sub-parallel, roughly E-W striking, steep structures (Fig. 4): (1) the Sangone fault system (SFS) in the northern part of the study area and (2) the Chisone Fault (CF) in the southern part. Between the SFS and the CF, some minor structures are present: (1) the NE-SW fault system, (2) the N-S striking Pinasca-Gran Dubbione fault system (PGFS), (3) the NW-SE striking Porte-Malanaggio Fault (PMF).

These faults bounds approximately homogeneous structural domains, characterised by a distinctive internal fault pattern.

The development of these structures has been influenced by the lithology: in the micaschists, the welldeveloped main schistosity, a composite fabric related to the D1 and D2 deformation phases, provides a suitable structural anisotropy for fabric reactivation during faulting; in these rocks, brittle shear zones are typically characterised by scarce lateral persistence and narrow damage zones and are widespread in the whole rock volume. In the more homogeneous metaintrusive rocks (metagranites, metadiorites and orthogneiss), brittle faulting is more localised (fault-damage zones up to several metres wide, and fault cores ranging from a few millimetres to 3 or $4 \mathrm{~m}$ ), and the faults usually cross-cut the metamorphic schistosity.

\section{Sangone fault system (SFS)}

At map scale, the SFS comprises several sub-parallel and discontinuous $\mathrm{E}-\mathrm{W}$-striking faults that reach about $5 \mathrm{~km}$ of trace length. These structures are usually sub-vertical and are linked by a few minor NE-SW faults up to $500 \mathrm{~m}$ long (Figs. 4, 7). The SFS is about $2 \mathrm{~km}$ wide and is developed mainly along the left side of the Lower Sangone Valley, where its morphology is characterised by the alignment of passes, ridges, scarps and straight valleys. Morphostructural elements ( $E-W$-striking lineaments, straight river incisions) indicate that these faults continue westward, for some kilometres, in the Sangone valley (Fig. 5). In the SFS, the deformation is distributed within steeply dipping, narrow cataclastic belts. Fault rocks are represented by cataclasites, foliated cataclasites with centimetre-scale thickness and rarely by non-cohesive tectonic breccias. The first-order faults are characterised by damage zones up to $10 \mathrm{~m}$ wide. At the mesoscale, these structures display a weakly anastomosed geometry in map view, outlined by metric to decametre-scale ENE-WSW- to ESE-WNW-striking fault segments that dip predominantly $60-80^{\circ}$ to the south. Quartz and chlorite slickenfibres indicate both left-lateral and left-normal senses of movement (Figs. 8a, 9a), although rare dextral senses of displacement have also been observed. A chlorite- and quartz-filled vein system with millimetre-scale thickness, sub-parallel to the faults, is also present, attesting to a minor extensional component along the SFS (Fig. 8a). The metamorphic foliation (ST), dipping about $30-40^{\circ}$ to the north, also has been reactivated at times by an extensional shear zone. 


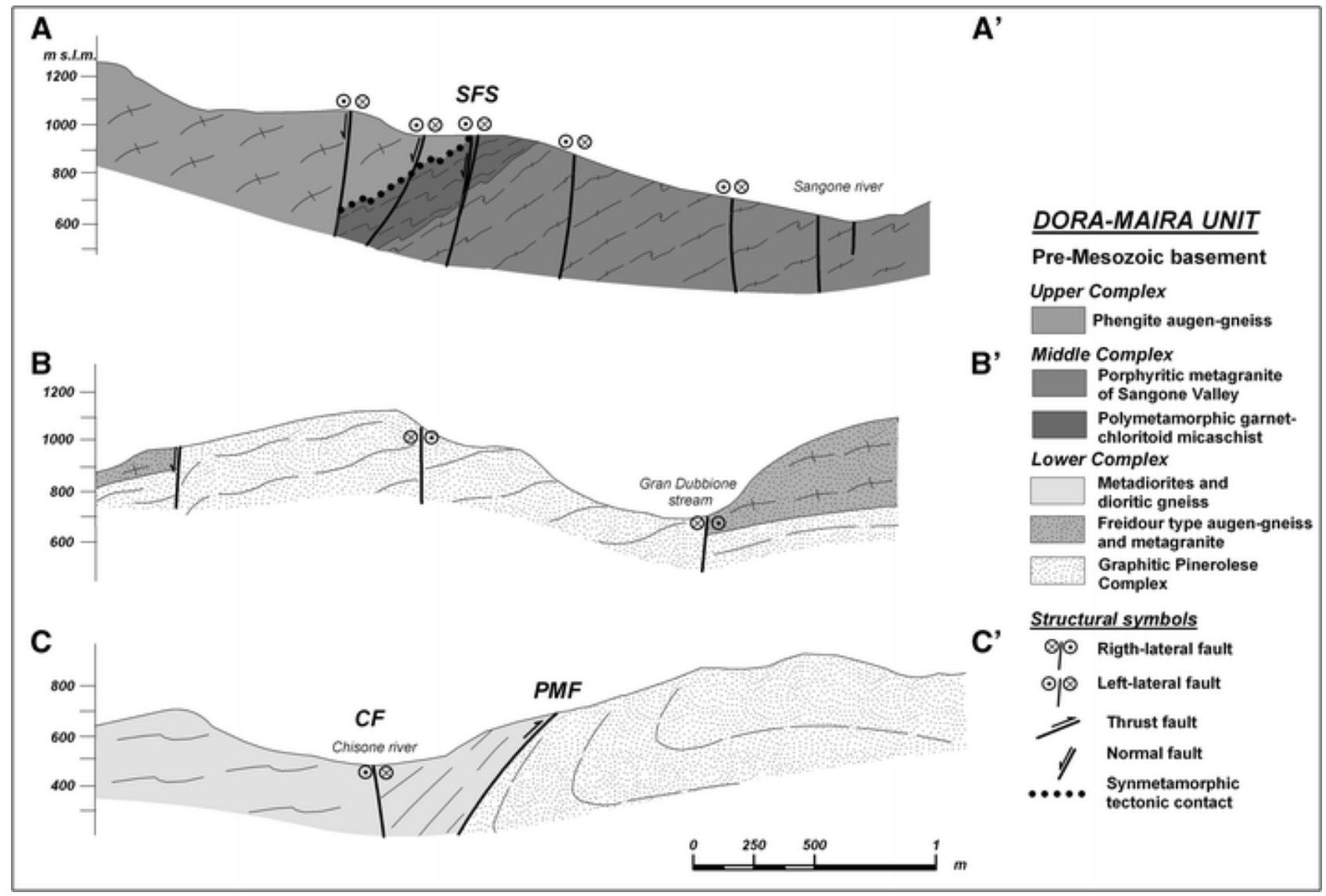

Fig. 7

Geological cross-sections of the study area. Traces of the cross-sections and abbreviations are shown in Fig. 4 


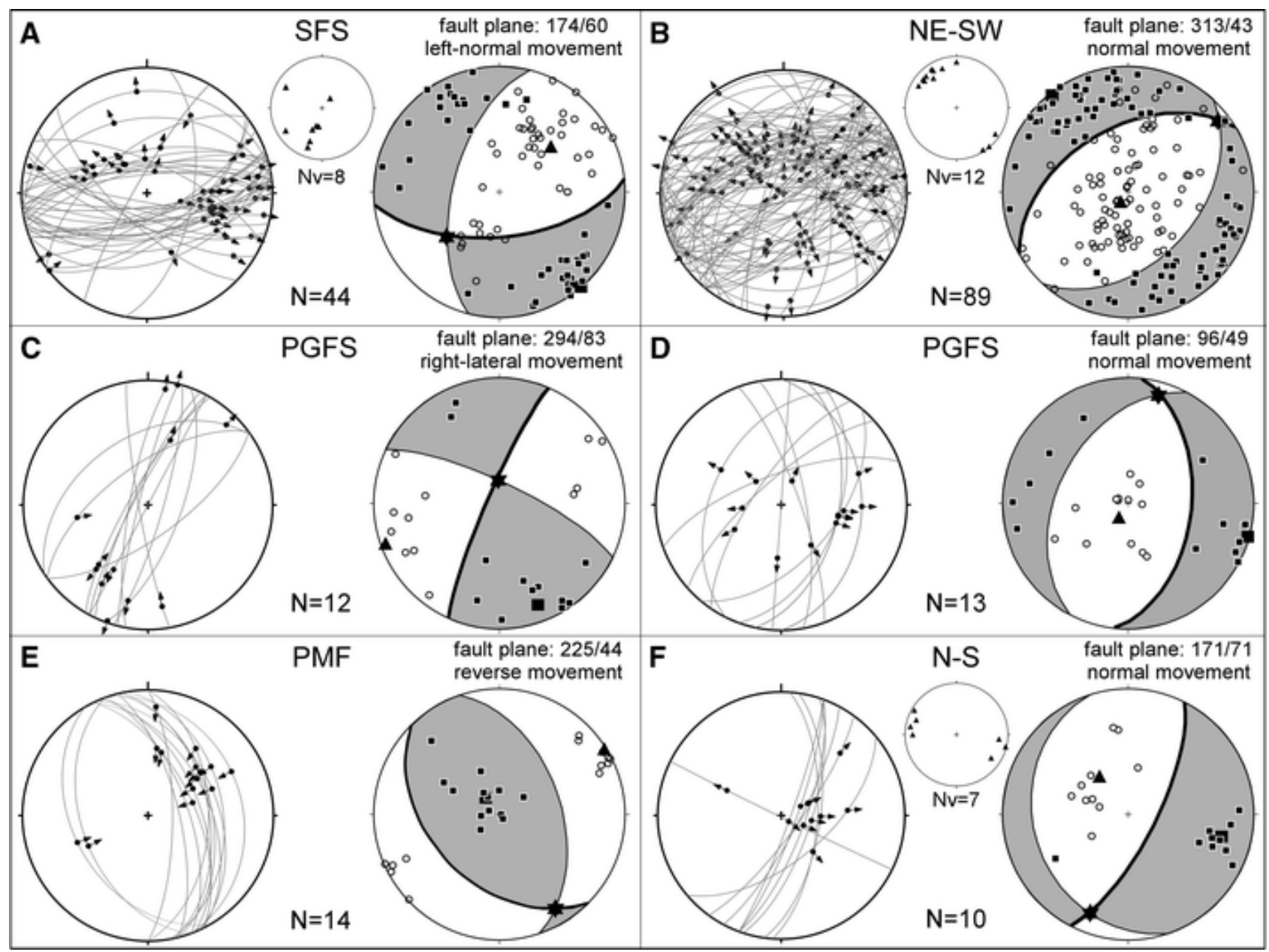

Fig. 8

Equal-area projections (lower hemisphere) showing fault-slip data for the different structural domains with related average kinematic solutions. The fault planes are represented as great circles, whereas the arrows indicate movement of the hanging wall of the faults; in $a, b$ and $f$, the small plots are related to the associated veins. $\mathrm{N}$ and $\mathrm{Nv}$ are the number of measurements of fault-slip data and veins, respectively. In the average fault plane solutions, grey and white areas represent the extensions and shortening quadrants, respectively. Open circles and black squares represent the $P$ and $T$ axes for each fault measured, and the great circles indicate the orientation of the two nodal planes. The triangle, star and square indicate the maximum, intermediate and minimum shortening axes for the average incremental strain solution. Bold great circles are modelled faults. The principal shortening $(P)$ and extension $(T)$ axes for the incremental strain tensor associated with each fault have been calculated by means of the software Faultkin (Allmendinger et al. 1991). This program assumes that the $P$ and $T$ axes for each fault plane lie at $45^{\circ}$ to both the fault normal and slip vector (slickenline orientation). Sense of slip allows the distinction between the $P$ and $T$ axes, and the intermediate axis lies perpendicular to both $P$ and $T$. The average orientations of the incremental strain axes were calculated using linked Bingham statistics. Abbreviations as in Fig. 4 

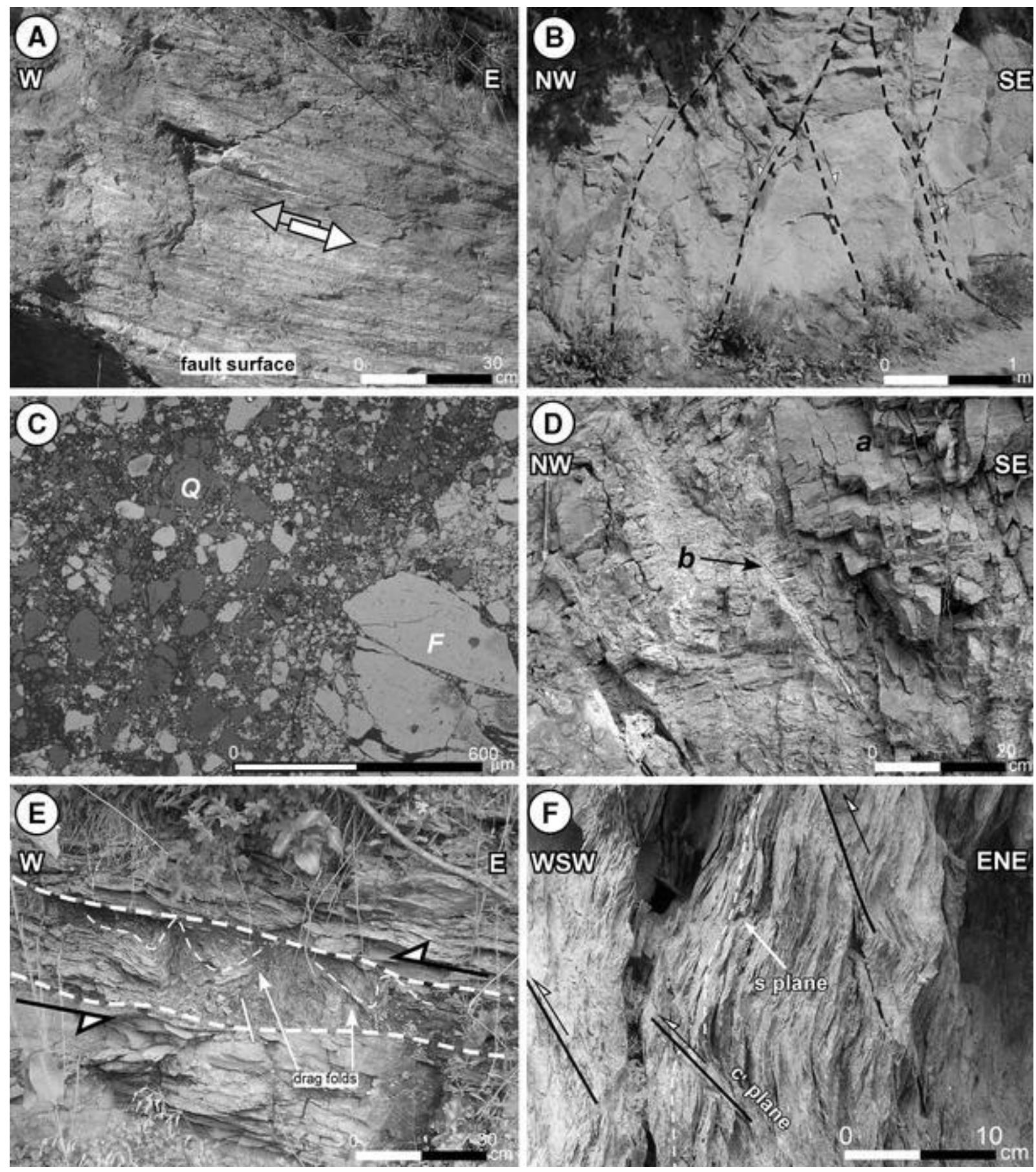

Fig. 9

a Sangone fault system. E-W striking left-lateral fault with quartz slickenfibres in augen-gneiss. b NE-SW fault system. Conjugate normal faults in metagranodiorites. c Pinasca Fault. Backscattered electron image of tectonic breccia in orthogneiss. Pure cataclastic process is involved in the grain-sized reduction of quartz (Q) and feldspars (F) without cement precipitation. d E-W faults with chlorite slickenfibres (a) cross-cut by $\mathrm{N}-\mathrm{S}$ faults (b), producing gouge with millimetric thickness (near Pinasca village). e W-verging reverse shear zone with associated drag folds in graphite micaschists (near Porte village). f Porte-Malanaggio Fault. Shear bands indicate reverse movement in graphite micaschists

\section{Chisone Fault (CF)}


The CF (Figs. 4, 7) reaches a length of about $5 \mathrm{~km}$ in the mapped area, but it could continue outwards in the adjoining sectors. It has been inferred along the $\mathrm{E}-\mathrm{W}$ segment of the Chisone River, where it separates two blocks, displaying different internal fault patterns and strain intensities.

\section{NE-SW fault system (NE-SW f.s.)}

The NE-SW f.s. is constituted, at map scale, by several steep and strongly discontinuous $\mathrm{N} 40^{\circ}-60^{\circ} \mathrm{E}$ faults, which reach a length of about $3 \mathrm{~km}$ and are widespread between the Sangone and Chisone Rivers (Fig. 4). These structures are well evident morphologically, as they strongly influence the hydrographical network (Fig. 5). $\mathrm{N} 40^{\circ}-60^{\circ} \mathrm{E}$ fault segments are characterised by very narrow damage zones, up to a few metres wide. Fault-related rocks are mostly represented by foliated cataclasites and cataclasites that reach centimetre-scale thickness. At the mesoscale, these faults dip mostly $50-70^{\circ}$ to the NW and are represented by discrete fault planes. These structures are usually characterised by normal and left-normal senses of movement (Fig. 8b), as indicated by Riedel shear-sense indicators and chlorite and quartz slickenfibres, and commonly are arranged in conjugate systems (Fig. 9b). Some of the NE-SW faults are linked by minor sinistral E-W faults, indicating that these structures are characterised by curved surfaces. At the mesoscopic scale, the $\mathrm{E}-\mathrm{W}$ faults periodically reactivate the metamorphic foliation, where they are favourably oriented, and are constituted by $N 70^{\circ}-100^{\circ} \mathrm{E}$ faults. Sub-parallel joints and chlorite-filled vein systems, some arranged in en echelon shear arrays, are also developed in correspondence with the NE-SW f.s. (Fig. 8b).

\section{Pinasca-Gran Dubbione fault system (PGFS)}

The (PGFS) is composed of three steeply dipping N-S faults up to $4 \mathrm{~km}$ long (Figs. 4, 7). Morphologically these structures are evidenced by straight, deeply incised or asymmetric valleys, by abrupt changes of the river's drainage direction, by steep scarps and ridges (Fig. 5).

The eastern and central faults display damage zones up to some metres wide, with an anastomosed geometry consisting of sub-vertical $\mathrm{N} 340^{\circ} \mathrm{E}$ - to $\mathrm{N} 30^{\circ} \mathrm{E}$-striking faults. At mesoscale, $\mathrm{S}-\mathrm{C}$ structures indicate that these faults are characterised by right-lateral movements (Fig. 8c), as also indicated at map scale by the restoration of the lithologic contact offset. Fault rocks associated to strike-slip faults are mostly represented by cataclasites.

Some mesoscale south-verging thrusts that usually reactivate the metamorphic schistosity in the graphite micaschists are widespread between those two faults. These structures may be interpreted as bridge structures (sensu Gamond 1987) that accommodated the localised fault-parallel shortening induced by the major $\mathrm{N}-\mathrm{S}$ transcurrent faults.

The western fault segment is characterised by a damage zone $50-60 \mathrm{~m}$ wide and by a metre-scale-thick fault core, with non-cohesive tectonic breccias, microbreccias and gouge (Fig. 9c). At the mesoscale, this structure is composed of roughly $\mathrm{N}-\mathrm{S}$ normal faults, with some arranged in conjugate systems (Fig. 8d). The rheology of the fault rocks (non-cohesive breccias) and the lack of quartz and chlorite mineralisation on the minor fault surfaces indicate that the fault formed under shallow crustal levels (less than $4 \mathrm{~km}$ with standard geothermal gradients; Sibson 1977). Cross-cutting relations (Fig. 9d), mainly observed at the mesoscale, moreover indicate that these faults clearly post-date the NE-SW f.s. Other minor $\mathrm{N}-\mathrm{S}$ faults, associated to the development of tectonic breccias, are also observed in the Chisola Valley and in correspondence with the Sangone fault system. 
The PMF is a reverse fault, reaching a length of about $3 \mathrm{~km}$, that superposed Malanaggio metadiorites in the hanging wall with graphitic micaschists in the footwall, which accommodated most of the deformation (Figs. 4, 7). At present, it is not possible to define the amount of displacement of this structure. The damage zone of the PMF reaches a decametre-scale width. Fault rocks are represented by foliated cataclasites up to $1 \mathrm{~m}$ thick. In correspondence with the PMF, the metamorphic foliation (ST) is rotated into the parallelism and reactivated by the NW-SE faults with the development of shear bands and drag folds that indicate a reverse sense of displacement with a minor dextral component (Figs. 8e, 9f).

\section{N-S fault system}

South of the Chisone Fault only a few N-S steeply dipping and strongly discontinuous faults up to $1 \mathrm{~km}$ long are widespread. These structures usually display a normal sense of movement (Fig. 8f) and are characterised by centimetre- to metre-scale damage zones. Chlorite and quartz fibres are usually widespread on the fault surfaces and in the associated vein systems, sometimes arranged in en echelon shear arrays (Fig. 8f).

The post-metamorphic structures also include $\mathrm{N} 350^{\circ} \mathrm{W}$ - to N30 E-trending folds (Fig. 10a) mainly developed at the mesoscopic scale mostly in the graphite micaschists and at times associated with low- to mediumangle N-S to NW-SE thrust faults (Figs. 9e, 10b, c). These folds display open to tight profiles, depending on the characteristics of the deformed rock type, and are usually characterised by western vergence. The absence of metamorphic recrystallisation indicates that these structures formed under brittle-ductile to brittle conditions. Some minor E-W thrust faults have also been rarely observed in the field (Fig. 10d). No cross-cutting relations among these different thrust systems have been observed.

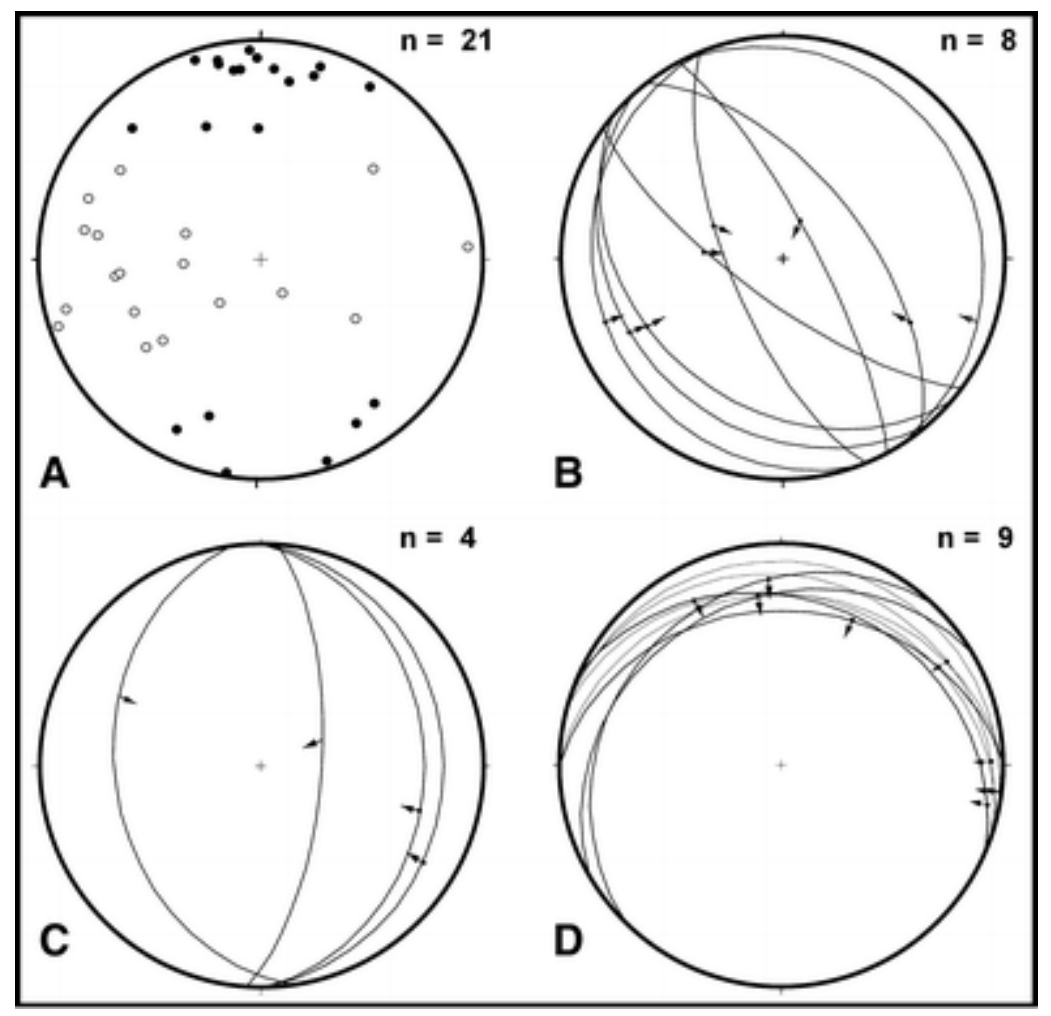

Fig. 10 
Equal-area projection (lower hemisphere), showing mesostructural data relative to post-metamorphic folds (a) and minor low-angle faults (b-d) in the analysed area. In a, black and open circles represent fold axes and fold axial planes, respectively

\section{Paleostrain analysis}

\section{Methodology}

In agreement with some authors (Claypool et al. 2002; Perello et al. 2004b; Rossetti et al. 2002), who worked in similar structural contexts, we preferred not to resolve the paleostress field, owing to the possibility that rigid rotation and tilting along boundaries of fault-bounded blocks (Gapais et al. 2000; Twiss and Unruh 1998), mechanical interaction among different faults (Dupin et al. 1993; Pollard et al. 1993; Nieto-Samaniego 1999) and reactivation of inherited anisotropies that cause the development of structures at angles different from those predicted by the Coulomb failure criterion (Harris and Cobbold 1984; Flodin and Aydin 2004) could occur as deformation proceeds. Therefore, in areas characterised by a long and complex tectonic evolution, like that analysed in this work, as already stressed by some authors (Marrett and Allmendinger 1990; Twiss and Unruh 1998), the assumptions on which is based the dynamic analysis (spatially and temporally homogeneous state of stress, isotropic material, absence of mechanical interaction among faults) are seldom satisfied. According to Twiss and Unruh (1998), if conditions on which paleostress inversion techniques are based on are not verified, the calculated paleostress principal directions should be conversely considered as directions of incremental shortening and elongation. By contrast, the paleostrain analysis, even if represents a more qualitative approach, requires less restrictive assumptions (faults may be considered as scale invariant and homogeneously distributed within the sampled rock mass) that may be satisfied also in such complex structural contexts.

In the light of this discussion, the analysis of fault-slip data is here carried out using the kinematic approach. The paleostrain analysis allowed us to determine the orientation of the principal axes (i.e. the $P$ and $T$ axes) of the strain ellipsoid, the bulk kinematics of the map-scale faults and the establishment of kinematic compatibility among different faults (see also Claypool et al. 2002, for a similar approach). This methodology, similarly to that used in the seismological studies, is based on the moment tensor summation which characterises infinitesimal strain due to fault rupture during an earthquake (Marrett and Allmendinger 1990). $\mathrm{P}$ and T axes are located at $45^{\circ}$ to the nodal planes of a fault plane solution and at $90^{\circ}$ from the intersection of the nodal planes (corresponding to the $\beta$ axis). According to Marrett and Allmendinger (1990), no interpretation is involved in the determining the kinematic axes of a fault from field measurements. The kinematic axes represent a simple and more immediate graphical representation of the original field data. When homogeneous fault populations are analysed, $\mathrm{P}$ and $\mathrm{T}$ axes show maxima concentrations, representing a solution for the orientation of the global incremental strain axes (Marrett and Allmendinger 1990; Twiss and Unruh 1998).

Because each fault system represents a domain of homogeneous deformation, the paleostrain analysis is here discussed integrating data collected in selected structural stations, mostly located in the correspondence of the map-scale faults (Fig. 11; Table 1), with data collected in each homogeneous structural domain (Fig. 8). An average kinematic solution is then calculated using the linked Bingham distribution statistics. This procedure allows determining the direction of the three axes of the incremental strain ellipsoid for the fault population (Marrett and Allmendinger 1990). This approach assumes that all faults are equally weighted (i.e. faults are considered as scale invariant). Fault-slip data were, therefore, not weighted in relation to fault displacement or fault dimension. The average fault plane solution calculated for each fault population shows, moreover, graphically the bulk kinematics of the different fault systems. 
The distribution of the $\mathrm{P}$ and $\mathrm{T}$ axes, together with the bulk fault plane solution for each fault system, is represented in separate plots (Fig. 8).

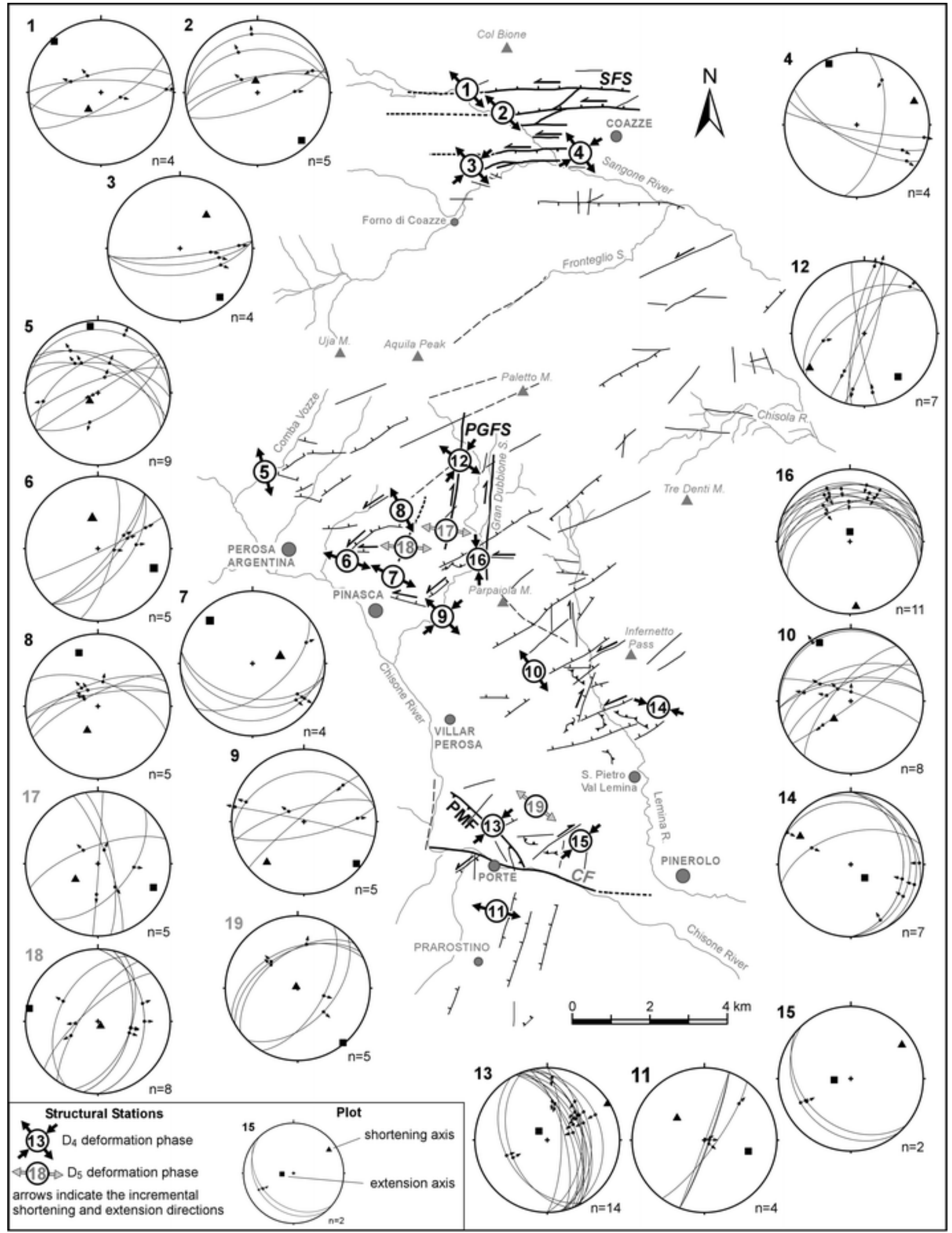

Fig. 11 
Fault network, with the direction of the strain axes obtained at single structural stations. Black and grey numbers in the circles indicate the structural stations related to the D4 and D5 phases, respectively (see text for explanation). The orientation of the average incremental maximum and minimum strain axes, determined with Bingham distribution statistics, is also shown

Table 1

\begin{tabular}{|l|l|l|l|l|l|l|l|l|}
\hline No Site & Longitude & Latitude & Altitude & $\lambda 1$ & $\lambda 2$ & $\lambda$ N & N \\
\hline 1 & $7^{\circ} 15.75^{\prime}$ & $45^{\circ} 15.75^{\prime}$ & 1000 & $317 / 5$ & $50 / 23$ & $217 / 66$ & 4 \\
\hline 2 & $7^{\circ} 15.58^{\prime}$ & $45^{\circ} 03.09^{\prime}$ & 940 & $137 / 11$ & $228 / 7$ & $351 / 77$ & 5 \\
\hline 3 & $7^{\circ} 16.15^{\prime}$ & $45^{\circ} 02.98^{\prime}$ & 750 & $141 / 14$ & $246 / 46$ & $38 / 41$ & 4 \\
\hline 4 & $7^{\circ} 16.28^{\prime}$ & $45^{\circ} 03.00^{\prime}$ & 750 & $335 / 8$ & $219 / 72$ & $68 / 15$ & 4 \\
\hline 5 & $7^{\circ} 11.66^{\prime}$ & $44^{\circ} 58.58^{\prime}$ & 1000 & $353 / 8$ & $85 / 10$ & $225 / 77$ & 9 \\
\hline 6 & $7^{\circ} 13.27^{\prime}$ & $44^{\circ} 57.72^{\prime}$ & 1010 & $109 / 19$ & $210 / 28$ & $350 / 55$ & 5 \\
\hline 7 & $7^{\circ} 13.35^{\prime}$ & $44^{\circ} 57.48^{\prime}$ & 915 & $315 / 18$ & $216 / 26$ & $75 / 57$ & 4 \\
\hline 8 & $7^{\circ} 14.65^{\prime}$ & $44^{\circ} 57.15^{\prime}$ & 835 & $340 / 22$ & $78 / 18$ & $204 / 60$ & 5 \\
\hline 9 & $7^{\circ} 15.08^{\prime}$ & $44^{\circ} 57.33^{\prime}$ & 805 & $129 / 8$ & $22 / 64$ & $222 / 25$ & 5 \\
\hline 10 & $7^{\circ} 17.65^{\prime}$ & $44^{\circ} 55.90^{\prime}$ & 593 & $332 / 9$ & $66 / 26$ & $224 / 62$ & 8 \\
\hline 11 & $7^{\circ} 16.25^{\prime}$ & $44^{\circ} 51.60^{\prime}$ & 800 & $104 / 37$ & $204 / 12$ & $309 / 50$ & 4 \\
\hline 12 & $7^{\circ} 14.87^{\prime}$ & $44^{\circ} 58.16^{\prime}$ & 1015 & $142 / 25$ & $351 / 62$ & $239 / 12$ & 7 \\
\hline 13 & $7^{\circ} 16.20^{\prime}$ & $44^{\circ} 53.43^{\prime}$ & 565 & $317 / 76$ & $150 / 13$ & $59 / 3$ & 14 \\
\hline 14 & $7^{\circ} 18.67^{\prime}$ & $44^{\circ} 55.23^{\prime}$ & 570 & $134 / 68$ & $31 / 5$ & $299 / 21$ & 7 \\
\hline 15 & $7^{\circ} 16.53^{\prime}$ & $44^{\circ} 53.82^{\prime}$ & 750 & $266 / 71$ & $149 / 9$ & $56 / 16$ & 2 \\
\hline 16 & $7^{\circ} 14.88^{\prime}$ & $44^{\circ} 57.33^{\prime}$ & 845 & $359 / 79$ & $265 / 1$ & $175 / 11$ & 11 \\
\hline 17 & $7^{\circ} 14.15^{\prime}$ & $44^{\circ} 57.78^{\prime}$ & 1005 & $113 / 18$ & $15 / 25$ & $235 / 59$ & 5 \\
\hline 18 & $7^{\circ} 15.58^{\prime}$ & $44^{\circ} 58.75^{\prime}$ & 1020 & $281 / 4$ & $11 / 4$ & $148 / 84$ & 8 \\
\hline 19 & $7^{\circ} 15.89^{\prime}$ & $44^{\circ} 53.70^{\prime}$ & 730 & $140 / 2$ & $50 / 0$ & $313 / 88$ & 5 \\
\hline
\end{tabular}

See Fig. 8 for the corresponding stereonets. $\lambda 1, \lambda 2$ and $\lambda 3$ are principal strain axes (trend, plunge) where $\lambda 1$ $>\lambda 2>\lambda 3$

Sense of shear indicators was obtained mainly by the measurement of quartz and chlorite slickensides, S-C structures, and by inflections of schistosity near the fault plane. Only best quality kinematic indicators were used to perform the paleostrain analysis.

\section{Data analysis}

As for the geometrical analysis, first, the kinematic analysis for the main structures (SFS) and afterwards the hierarchically associated minor structures (NE-SW f.s., PGFS, PMF, N-S f.s.) are discussed. Since no faultslip data are available for the Chisone Fault, it was not possible to perform the paleostrain analysis. 
Fault-slip data (Fig. 8a; stations 1, 2, 3, 4 of Fig. 11) show mostly left-lateral to left-normal and subordinately normal movements. Paleostrain analysis indicates that these faults are consistent with mostly sub-horizontal to moderate north-eastward dipping and subordinately steeply dipping $\mathrm{P}$ axes with constant sub-horizontal NNW-SSE- to NW-SE-trending T axes (Fig. 8a). Because both transcurrent and transtensive/normal faults show the same fault rocks (cohesive and foliated cataclasites) and mineralisations (albite, chlorite and quartz) on fault surfaces, we associate these different movements to a single transtensive faulting stage. The variability of the shortening direction is therefore interpreted in terms of partitioning of the transcurrent and normal component of movement (see also Depaola et al. 2005) along the SFS.

The average fault plane solution shows left-normal displacement on a fault plane that on average strikes $84^{\circ} \mathrm{E}$ and dips $60^{\circ} \mathrm{S}$ (Fig. 8a) with a shortening axis moderately dipping NE and a sub-horizontal extension axis.

\section{NE-SW fault system}

The normal and normal-left movements along the dominant NE-SW fault system are consistent with mostly moderate to steeply dipping shortening axes with sub-horizontal NW-SE extension (Fig. 8b and stations 5, 6, 7, 8, 10 in Fig. 11). A NE-SW sub-horizontal shortening direction is instead associated with the subordinate E-W left-lateral faults (station 9 in Fig. 11). Normal and transtensive movements along the NESW faults are interpreted as associated to a single faulting stage, as these show the same fault rocks (cohesive and foliated cataclasites) and mineralisations (albite, chlorite and quartz) on faults surfaces, as already described also for the SFS. The bulk kinematic fault plane solution that incorporates all of the data sets for these faults shows normal displacement along a moderately NW-dipping fault plane, consistent with a steep shortening axis and a roughly NW-SE sub-horizontal extensional axis (Fig. 8b).

Paleostrain analysis has not been carried out for the dextral movements observed along these faults because their paucity. These last movements may be related to block rotations between $\mathrm{E}-\mathrm{W}$ striking sinistral major faults (SFS and CF) or associated to a further faulting stage. No overprinting relations have been found between the different senses of movement allowing to constrain with accuracy the tectonic interpretation of these data.

\section{Pinasca-Gran Dubbione fault system}

Paleostrain analysis for the right-lateral faults (eastern and central faults; see above) shows sub-horizontal NE-SW shortening and NW-SE extension axes (Fig. 8c; station 12 in Fig. 11). The bulk fault plane solution indicates for these faults right-lateral displacements on a fault plane that on average strikes $\mathrm{N} 20^{\circ} \mathrm{E}$ and dips $85^{\circ}$ to the WNW (Fig. 8c). The roughly E-W thrust faults widespread between these $\mathrm{N}-\mathrm{S}$ faults, consistent with a $\mathrm{N}-\mathrm{S}$ shortening direction (station 16 in Fig. 11), may have accommodated a local shortening induced by the mechanical interaction between the $\mathrm{N}-\mathrm{S}$ right-lateral fault.

The fault-slip data related to the normal faults (western fault segment, see above) are instead consistent with a steeply dipping shortening direction and with an ENE-WNW extension direction (Fig. 8d; stations 17, 18 in Fig. 11). The bulk fault plane for this fault population corresponds to a fault plane moderately dipping to the east (Fig. 8d). Fault rocks (tectonic microbreccias and gouge) indicate that normal faults formed at shallower crustal levels than the strike-slip faults (cataclasites; Sibson 1977; Scholz 1988). N-S normal faults moreover cross-cut the NE-SW normal faults in the field (Fig. 9d). 
The kinematic analysis of associated NNW-SSE minor shears, interpreted as Riedel shears of the PMF, yields $\mathrm{NE}-\mathrm{SW}$ shortening axes with a sub-vertical extension. The modelled fault orientation, parallel to the average strike of the measured fault population, shows reverse displacement, with a minor dextral component, on a plane that dips $44^{\circ}$ to the SW (Fig. 8e, station 13 in Fig. 11).

\section{N-S fault system}

Normal movements on the dominant $\mathrm{N}-\mathrm{S}$ faults are consistent with an average sub-vertical shortening and with an average E-W to WNW-ESE extension (Fig. 8f; station 11 in Fig. 11). The bulk fault plane solution indicates normal movements on a steeply dipping NNE-striking fault plane.

The low-angle-dipping thrust faults, occasionally observed in the graphitic micaschists, are mostly consistent with a NE-SW (station 15 in Fig. 11) or with a WNW-ESE (station 14 in Fig. 11) shortening direction.

\section{Synthesis of the data}

In Fig. 11, which shows the strain pattern in the analysed area, T axes are mostly sub-horizontal and on average trend $\mathrm{NW}-\mathrm{SE}$, whereas $\mathrm{P}$ axes display quite variable orientations, as those are influenced by the kinematics of the map-scale structures. In synthesis:

- sub-horizontal NE-SW- to ENE-WSW-trending P axes are observed close to the SFS in the northern sector of the area (stations 3, 4), of the PGFS in the central part (station 12) and of the PMF in the southern part (station 13). Also structural stations in correspondence with minor $\mathrm{E}-\mathrm{W}$ faults (station 9) and with the minor thrust faults furnish sub-horizontal NE-SW- to ESE-WNW-trending P axes (stations 14, 15);

- sub-horizontal N-S-trending P axes (station 16 ) are mostly concentrated between the $\mathrm{N}-\mathrm{S}$ strikeslip faults of the PGFS;

- steeply dipping P axes with mostly NW-SE- to NNW-SSE-trending T axes are widespread in the central part of the area, where the NE-SW fault system is well developed (stations 5, 6, 7, 8, 10) and in correspondence with the SFS (stations 1, 2);

- steeply dipping $\mathrm{P}$ axes with $\mathrm{E}-\mathrm{W}$-trending $\mathrm{T}$ axes are observed south of the Chisone Fault (station 11), where a minor and discontinuous $\mathrm{N}-\mathrm{S}$ fault system is developed, and in correspondence with the western fault of the PGSF (station 17, 18)

\section{Discussion}

\section{Post-metamorphic structural evolution of the mapped area}

On the basis of the geometrical, cross-cutting relations and paleostrain analysis, two main homogeneous fault populations have been distinguished, characterised by different orientations of the maximum and minimum shortening axes ( $\mathrm{P}$ and $\mathrm{T}$ axes) and by dissimilar fault-related rocks (cataclasites and foliated cataclasites versus tectonic breccias, microbreccias and gouge). In the following description, these fault populations will be related to two distinct faulting stages, named D4 and D5 phase. Table 2 summarises the kinematics and characteristics of the structures related to each phase. 
Table 2

Correlation of the characteristics of structures, fault rocks and orientation of strain axes associated with the D4 and D5 phases

\begin{tabular}{|c|c|c|c|c|c|c|c|c|c|}
\hline \multirow{2}{*}{$\begin{array}{c}\text { Deformation } \\
\text { event }\end{array}$} & \multicolumn{6}{|c|}{ Sense of movement of faults } & \multirow{2}{*}{ Fault rocks } & \multirow{2}{*}{ Slickenfibres } & \multirow{2}{*}{$\begin{array}{l}\text { Orientation of } \\
\text { strain axes }\end{array}$} \\
\hline & $N E-S W f . s$ & PGFS & SFS & $P M F$ & $N$-Sf.s. & other structures & & & \\
\hline$D_{4}$ & normal & $\begin{array}{l}\text { Right- } \\
\text { lateral }\end{array}$ & $\begin{array}{c}\text { Left-lateral } \\
\text { with minor } \\
\text { normal } \\
\text { component }\end{array}$ & $\begin{array}{l}\text { Reverse } \\
\text { with minor } \\
\text { dextral } \\
\text { component }\end{array}$ & normal & $\begin{array}{l}\text { Minor NE- and } \\
\text { SW-verging } \\
\text { thrust faults } \\
\text { NNW-SSE folds }\end{array}$ & $\begin{array}{l}\text { Cataclasites } \\
\text { and foliated } \\
\text { cataclasites }\end{array}$ & $\begin{array}{c}\text { chlorite, } \\
\text { quartz, albite }\end{array}$ & $\begin{array}{c}\text { NE-SW to } \\
\text { ENE-WSW } \\
\text { shortening } \\
\text { direction and } \\
\text { NW-SE to } \\
\text { NNW-SSE } \\
\text { extension } \\
\text { direction }\end{array}$ \\
\hline$D_{5}$ & normal & normal & & & & & $\begin{array}{l}\text { Incohesive } \\
\text { breccias, } \\
\text { gouge }\end{array}$ & $\begin{array}{c}\text { no } \\
\text { slickenfibres }\end{array}$ & $\begin{array}{c}\text { Sub-vertical } \\
\text { shortening } \\
\text { direction and } \\
\text { ENE-WSW } \\
\text { extension } \\
\text { direction }\end{array}$ \\
\hline
\end{tabular}

Grey cells no available data. Abbreviations as in Fig. 4

The geometry, kinematics and hierarchical relations of the faults mapped in this work, shown in Fig. 12, are in good agreement with the structural association of an $\mathrm{E}-\mathrm{W}$ left-lateral shear zone, with a minor extensional component of movement (Sanderson and Marchini 1984), whose development is here related to the first faulting stage (D4 phase). The northern and southern boundaries of this shear zone, about 15 $\mathrm{km}$ wide, correspond to two sub-parallel, steeply dipping discontinuities: the Sangone fault system and the Chisone Fault. The NE-SW faults represent minor extensional splays, with a minor sinistral component, branching from the Sangone fault system and bounded on the south by the Chisone Fault. The rare dextral movements associated to the NE-SW faults may be related, in the analysed area, to the counterclockwise rotation of blocks bounded by major E-W faults. The steep, roughly N-S-striking Pinasca-Gran Dubbione fault system (PGFS), characterised by a dextral sense of movement, is interpreted as an antithetical structure ( $R^{\prime}$ shear) with respect to the two major boundary structures, whereas the PMF, characterised by a strong reverse component of displacement, is considered as a NW-striking contractional splay of the Chisone Fault. The low-angle NE- and SW-verging thrust faults and the NNW-SSE to N-S-trending folds (Fig. 10a) accommodate the shortening in the pervasively foliated graphite micaschists, whereas the mesoscale $\mathrm{S}$-verging thrusts, widespread between $\mathrm{N}-\mathrm{S}$ striking transcurrent faults, may be interpreted as minor shortening structures formed between these sub-parallel right-lateral faults. The discontinuity, the scarce lateral persistence, the angular relationship among the structures and the poor displacement accommodated indicate that this $\mathrm{E}-\mathrm{W}$ shear zone has been poorly evolved. The angular relation between the extensional features (NE-SW f.s.) and the E-W boundary faults ( $\alpha$ angle in Fig. 12b; Kelly et al. 1998; Rossetti et al. 2002) indicate that these structures accommodated a NE-SW to ENE-WSW shortening direction. Transcurrent and transtensive/extensional movements along these different fault systems are associated to a single faulting stage as they show the same rheological characteristics (fault rocks and mineralisations on fault surfaces, see above). On the basis of these similarities, the coexistence of transcurrent and normal faults is, therefore, interpreted as induced by a bulk transtension along the considered $\mathrm{E}-\mathrm{W}$ shear zone. 


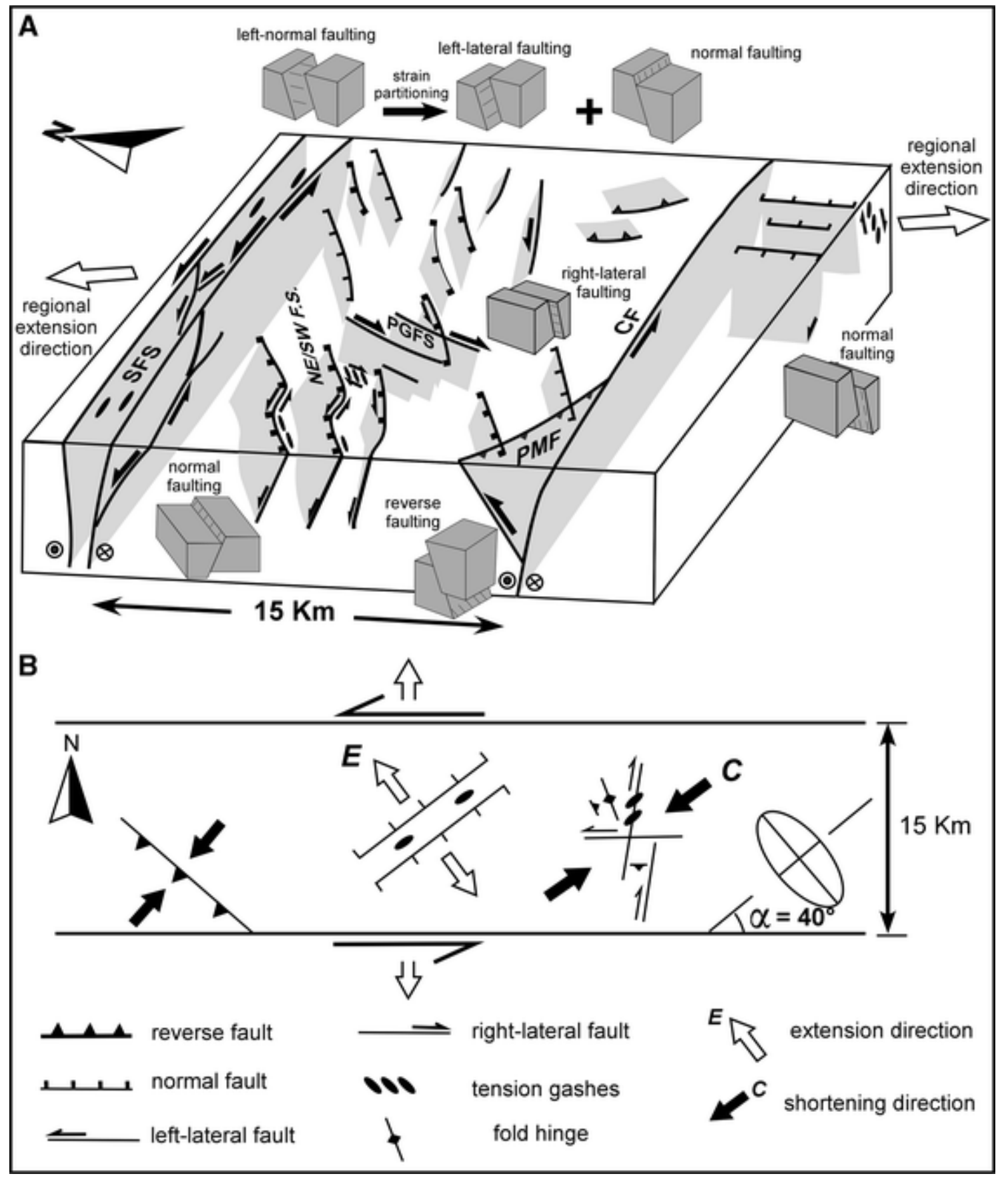

Fig. 12

a 3D-conceptual block diagram showing the hierarchical and geometrical relations among the D4-related faults in the study area. $b$ Plan view showing the geometrical and kinematic relations of the D4 structural association. Abbreviations as in Fig. 4

The paleostrain analysis of the fault-slip data (Figs. 8, 11,13c) indicates a kinematic compatibility with a steady, sub-horizontal NW-SE extension direction, whereas the shortening axis varies from sub-horizontal (in correspondence with the SFS, PGFS, PMF and minor thrust faults) to steeply dipping (in correspondence with the SFS and the NE-SW fault system) along an average NE-SW direction. The complex distribution of the $P$ axes is both related to the kinematics of the different fault systems and to the strain partitioning along these structures that also caused the permutation between maximum and intermediate shortening axes. It is, however, not excluded that the normal/transtensive movements may be associated to an 
extensional reactivation, probably related to the subsequent faulting stage (D5 phase), even if no clear overprinting relations were found allowing to constrain this interpretation. 

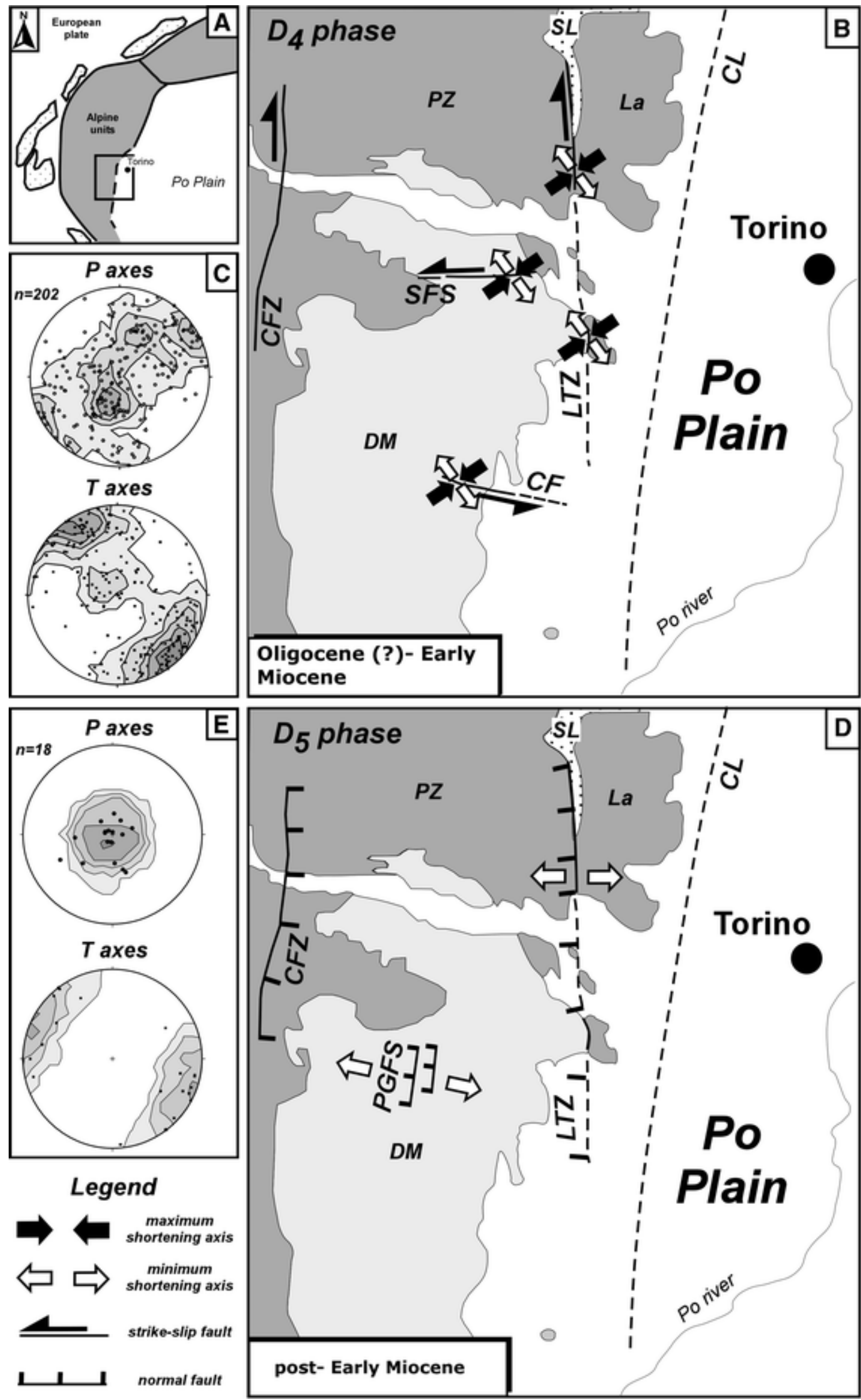
Fig. 13

Schematic tectonic sketches showing the post-collisional tectonic evolution of the Northern Cottian Alps. a Location of the analysed area. b Oligocene (?) to Early Miocene tectonics: N-S right-lateral regional faults and minor E-W sinistral antithetical faults developed in this sector of the Western Alps. The geometry and kinematics of these structures are in agreement with an average NW-SE extension and with a subhorizontal NE-SW shortening. c post-Early Miocene tectonics: pre-existing N-S structures are reactivated as normal faults, whose kinematics are consistent with a steep shortening axis and a WNW-ESE extension. $d$, e equal-area lower hemisphere projections, showing the cumulative P and T axes for the D4 and D5 phases obtained by mesoscale fault measurements in the area mapped in this study. Contours at 2 times uniform

Assuming a geothermal gradient of about $30^{\circ} \mathrm{C} / \mathrm{km}$, as also proposed by Malusà et al. $(2005,2009)$, this structural association may have formed from 4 to $10 \mathrm{~km}$ of depth (Sibson 1977; Scholz 1988), as the faultrelated rocks are represented mainly by foliated cataclasites and chlorite, quartz and rarely albite are the predominant mineralisations observed on the fault surface and in the associated vein systems. These last features also indicate that this faulting event occurred in the presence of fluids.

The development of $\mathrm{N}-\mathrm{S}$ normal faults (Figs. 8d, 11, 13e) and a pervasive jointing in the whole study area may be related to a subsequent faulting stage (D5 phase). This interpretation is based on the characteristics of fault rocks (incohesive tectonic breccias, microbreccias and gouge) indicating that these structures formed under very shallow crustal levels (1-4 km of depth; Sibson 1977; Scholz 1988), where purely frictional mechanisms were dominant in the absence of fluids, as suggested by the lack of mineralisation and veins within fault-damage zones. The hypothesis of a younger deformation is supported moreover by the cross-cutting relations between these $\mathrm{N}-\mathrm{S}$ normal faults and the $\mathrm{E}-\mathrm{W}$ and the NE-SW fault system (Fig. 9d). The geometry and kinematics of the D5 faults are consistent with an ESE-WNW extension and with a sub-vertical shortening, as also indicated by the paleostrain analysis of fault-slip data (Figs. 8d, 11, 13e).

\section{Correlation with the adjacent sectors of the Northern Cottian Alps}

The post-collisional tectonic evolution of the Northern Cottian Alps will be defined by constraining the kinematic evolution of the analysed area with that of the adjoining domains and with the available fission track data.

The geometry and the scarce displacements accommodated by the analysed structures indicate that the fault network is part of a poorly deformed block. Because both the SFS and the CF are not observed to cross-cut the Lis-Trana Deformation Zone, this last may be assumed as the eastern boundary of this block. The right-lateral movements along the LTZ are consistent with a roughly NE-SW shortening direction and a sub-horizontal NW-SE extension direction (Balestro et al. 2009a), which is compatible with that characterising the first faulting stage (D4 phase, see Fig. 13b, c). On the basis of these data, the LTZ is interpreted as a first-order structure, whereas the SFS and the CF could represent second-order antithetical faults, characterised by a strong sinistral component of movement (Fig. 13b). The NE-SW f.s., the PGFS and the PMF could thus represent third-order faults developed between the SFS and the CF.

Though the westward terminations of the SFS and the CF are still not known, the western boundary of the considered block may be represented by the Colle delle Finestre Deformation Zone (CFZ; Cadoppi et al. 2002b, 2007; Tallone et al. 2002), as west of this structure E-W striking faults are not present and the main brittle tectonic feature is represented by the Transverse Fault system (see Figs. 1, 2). 
The subsequent faulting stage (D5 phase), in the analysed area related to the development of $\mathrm{N}-\mathrm{S}$ normal fault, is consistent with an ESE-WNW extension direction with a steep shortening direction. In spite of their paucity, these data are consistent with the extensional reactivation of the LTZ and CFZ in the adjoining domains (Fig. 13d, e; Cadoppi et al. 2007; Balestro et al. 2009a). This indicates that an extensional tectonic regime affected the entire crustal block, principally reactivating the $\mathrm{N}-\mathrm{S}$ discontinuities as normal faults, although the extensional reactivation of the other fault systems may not be excluded, as transtensive and normal movements have been found along these faults.

The lack of geological markers does not allow us unquestionably to constrain the timing of these faulting stages, but zircon (ZFT) fission track $\left(\mathrm{TC}=240 \pm 30^{\circ} \mathrm{C}\right.$, natural $\alpha$-damage model of Reiners and Brandon 2006, or Tc $=340 \pm 40^{\circ} \mathrm{C}$, zero damage model of Brix et al. 2002, Rahn et al. 2004) and apatite (AFT) fission track data ( $T C=110 \pm 10^{\circ} \mathrm{C}$, Reiners and Brandon 2006) furnish an important timing constraint, reducing the wide time span. According to the two proposed models, the closure temperature of the ZFT, with a geothermal gradient of $30^{\circ} \mathrm{C} / \mathrm{km}$, may correspond to depth ranging between 7 and $12 \mathrm{~km}$. The closure temperature of the AFT, instead, corresponds to depth of 3-4 km. In Fig. 2, showing the published FT data for the Northern Cottian Alps (Bernet et al. 2001; Cadoppi et al. 2002a; Balestrieri et al. 2004; Malusà et al. 2005; Tricart et al. 2007), the zircon ages range between 34.6 and 29.7 Ma, whereas the apatite ages range mostly between 27 and $13.1 \mathrm{Ma}$, although two data give significantly older ages (34 and $41.1 \mathrm{Ma}$ ). In the light of the aforementioned assumptions, these data indicate that this sector of the Western Alps reached a depth compatible with the development of cataclasites (4-10 km, Scholz 1988), since the Oligocene times. Deformation conditions roughly compatible with the development of tectonic breccias and gouge (1-3 km of depth, Scholz 1988) were reached since in the Late Oligocene-Early Miocene. On the basis of these considerations, we propose that the D4 phase may have occurred between the Oligocene-Early Miocene and that the D5 phase may be considered merely as post-early Miocene. Pleistocene deposits dislocated by $\mathrm{N}-\mathrm{S}$ normal faults along the CFZ (Cadoppi et al. 2007) suggest that this extensional regime could have been protracted up to the Quaternary times.

Both focal solutions of recent earthquakes (Eva et al. 1997; Sue et al. 1999; Delacou et al. 2004; Béthoux et al. 2007; Perrone et al. 2009b, submitted) and GPS data (Calais et al. 2002; Delacou et al. 2008) indicate that the inner sector of Western Alps is still undergoing an E-W to ESE-WNW extension. In the analysed area, this extension direction corresponds well with that observed for the second faulting stage and may be related to the present-day activity of $\mathrm{N}-\mathrm{S}$ normal and/or oblique-normal faults, as proposed by Eva et al. (1997) and by Perrone et al. (2009b).

\section{Implications for the post-collisional tectonics of the Western Alps}

The post-collisional tectonics of the Northern Cottian Alps represents a further constraint for understanding the geodynamic mechanism that has driven the tectonic evolution of the Western Alps since the late Oligocene, which is currently under debate (Collombet et al. 2002; Champagnac et al. 2006; Sue and Tricart 2003; Sue et al. 2007a; Delacou et al. 2004, 2008; Perello et al. 2004b; Malusà et al. 2005, 2009). Different tectonic regimes have been described for the Western Alps, moving from the internal to the external zones. In Fig. 14 are summarised the structural (including both kinematic and dynamic data), seismological and geodetic data available in the literature for the Neogene to Present-day tectonics of the Western Alps. 

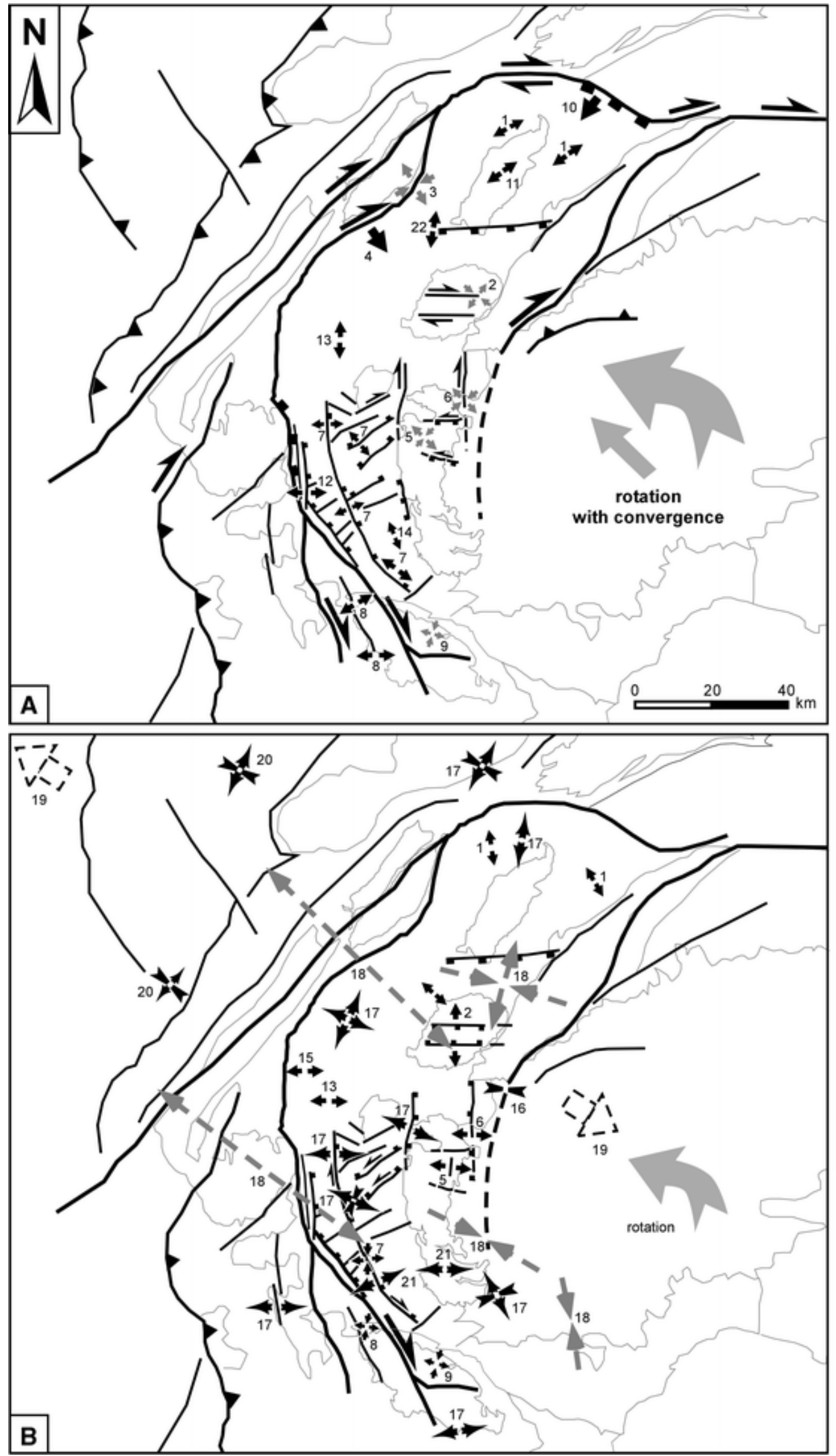

strike-slip fault

Fig. 14 
Schematic tectonic sketches showing two hypothetical steps of the post-Oligocene to present-day tectonics in the Western Alps as proposed in this study (after Sue and Tricart 2003). a The counterclockwise rotation with the convergence between Adria and Europe induces dextral movements along the major faults parallel to the trend of the Alpine belt (Oligocene?-Early Miocene?). b The convergence between the Adria and European plates decreases, and gravitational forces become predominant on the rotational boundary movements in the inner Western Alps, inducing an orogen-perpendicular extensional regime in the inner Western Alps (Early Miocene?-Present). Reference indexes on the map are (1) Champagnac et al. (2004), (2) Perello et al. (2004b), (3) Perello et al. (1999), (4) Seward and Mancktelow (1994), (5) this study, (6) Balestro et al. (2009a), (7) Sue and Tricart (2003), (8) Labaume et al. (1989), (9) Baietto et al. (2009), (10) Mancktelow (1992), (11) Bistacchi et al. (2000), (12) Sue and Tricart (1999), (13) Champagnac et al. (2006), (14) Tricart et al. (2004), (15) Ceriani and Schmid (2004), (16) Eva et al. (1997), (17) Delacou et al. (2004), (18) Calais et al. (2002), (19) Vigny et al. (2002), (20) Kastrup et al. (2004), (21) Sue et al. (1999), (22) Malusà et al. (2009)

The post-metamorphic kinematic evolution described in this work fits well in a model where the major faults bounding the inner Western Alps accommodated dextral movements, induced by the counterclockwise rotation of the Adria plate since the Oligocene. At regional scale, in the Oligocene(?)Early Miocene(?), the rotation and convergence between Adria and Europe (Fig. 14a) induced dextral strikeslip tectonics, parallel to the trend of the Alpine belt, both along the External Cristalline Massifs (ChamonixRhone Line; Gourlay and Ricou 1983) and, in the innermost part of the chain, along the Canavese Line (Late Oligocene; Schmid et al. 1987). The coeval extensional activity of the Simplon Line, in this model, is interpreted as an effect induced by the kinematic interaction between the Rhone Line and the Insubric Line (see also the interpretation proposed by Hubbard and Mancktelow 1992). Alpine compressive thrust fronts propagated both in the Helvetic zone (Late Oligocene-Early Miocene; Butler et al. 1986) and in the Po Plain (Late Oligocene; Mosca et al. 2009). In the inner Western Alps, bounded by these regional fault systems, a bulk transtensive regime was established, owing to the interaction between rotational movements and body forces active inside the chain. In the Northern Cottian Alps, right-lateral N-S major faults (LTZ) and minor antithetical E-W faults (SFS) developed, whereas in the adjacent Briançon and Queyras areas, the Longitudinal and Transversal fault systems were active as normal faults (Sue and Tricart 2002, 2003; Tricart et al. 2004; Schwartz et al. 2008). In the Gran Paradiso Unit E-W striking, right-lateral faults also are active (Perello et al. 2004b). Along the Penninic Frontal Thrust, evidence of extensional reactivation was found in the Valais and Briançòn area (Cannic et al. 1999; Sue and Tricart 1999; Ceriani and Schmid 2004) whereas dextral-reverse movements were found by Perello et al. (1999) in the Courmayeur area (Aosta valley). In the inner North-Western Alps, a bulk transtensive regime was found (Champagnac et al. 2004, Malusà et al. 2009) that also caused the extensional activity of the Aosta-Ranzola Fault.

Starting form the Early Miocene (Fig. 14b), the convergence between the Adria and European plates decreases, and gravitational forces become predominant on the rotational boundary movements in the inner Western Alps, where an orogen-perpendicular extensional regime was established. The kinematics of the major faults in the Northern Cottian Alps (Balestro et al. 2009a), the Gran Paradiso (Perello et al. 2004b), Aosta and Valais (Champagnac et al. 2004, 2006) area change from transcurrent to normal. Only in the Briançon and Queyras areas (Sue and Tricart 2003) and in the internal Argentera Massif (Tricart 2004; Baietto et al. 2009), strike-slip tectonics prevailed up to the Pliocene times.

The brittle extensional tectonics observed in the different domains of the inner Western Alps (Fig. 14) may be related to the buoyancy forces inside the chain, as proposed by Sue and Tricart (2003). The coexistence of two different driving forces (counterclockwise rotation and buoyancy forces) may have induced strain 
partitioning and, subsequently, complex spatial and chronological relations between transcurrent and extensional movements on a regional scale (see also Champagnac et al. 2006). Therefore, in the analysed area, the transition from the first faulting stage, characterised by a bulk NE-SW shortening direction with a NW-SE extension, to the second, consistent with a roughly ESE-WNW extension and a steep shortening direction, is interpreted as a tectonic continuum, related to the prevalence of the buoyancy forces on the strike-slip movements. It may have also caused the permutation between maximum and intermediate shortening axes ( $\mathrm{Hu}$ and Angelier 2004) with a roughly constant extension direction $\left(20^{\circ}-30^{\circ}\right.$ of difference between the two faulting stages; see Fig. 13d, e). Both GPS data (Calais et al. 2002; Delacou et al. 2004, 2008), and seismological data (Eva et al. 1997; Sue et al. 1999; 2007a; Delacou et al. 2004; Perrone et al. 2009b, submitted) show how the orogen-perpendicular extension is still ongoing in the core of the chain, while in the outer limits of the chain, a transpressional regime is still prevalent. The low-grade magnitude of the present-day seismicity, moreover, indicates that tectonic deformation in the inner Western Alps is scarce, even if recent researches showed that only one-third of the deformation is currently accommodated by the seismic activity (Sue et al. 2007b). This kinematic model is also supported by the crustal-scale geodetic data, indicating that the counterclockwise rotation of the Adria plate is still ongoing (Nocquet and Calais 2003).

The south-westward extrusion model hypothesised by some authors (Hubbard and Mancktelow 1992; Champagnac et al. 2006; Sue et al. 2007a), characterised by an overall extension direction parallel to the trend of the belt, seems not in agreement with our data. This model in fact predicted in the most internal sector of the Western Alps sinistral movement along faults parallel to the chain, like the LTZ, which have not been observed.

\section{Summary and conclusions}

New field and structural data, integrated with morphotectonic analysis, allowed us to characterise the geometry and the kinematic evolution of the fault network in a key area of the Western Alps. The available thermo-chronological data in the analysed area suggest that the post-metamorphic evolution, characterised by two main faulting stages, began since the late(?) Oligocene.

Two roughly E-W structures represent the major post-metamorphic features, the Sangone fault system and the Chisone Fault. Between these faults, some minor structures developed, whose geometry and kinematics are consistent with those of an $\mathrm{E}-\mathrm{W}$ brittle shear zone, here related to the earlier faulting stage (D4), with a normal component of movement. Kinematic analysis of fault-slip data indicates that these structures accommodated a roughly sub-horizontal to steeply dipping NE-SW shortening and a NW-SE extension. The geometry and small displacement suggest that these structures are part of a poorly strained block bounded by highly strained tectonic discontinuities, which could correspond to the LTZ and to the $\mathrm{CFZ}$, two regional $\mathrm{N}-\mathrm{S}$ right-lateral structures representing the most important features of the Northern Cottian Alps. In this geometrical model, the SFS and CF would represent two-second-order antithetical structures of the LTZ and the CFZ. The change from right-lateral to normal movements of the $\mathrm{N}-\mathrm{S}$ structures that affect the analysed area, consistent with an average $\mathrm{E}-\mathrm{W}$ extension and with steep shortening, is related to the second faulting stage (D5 phase) and may possibly have been caused by the permutation between the maximum and intermediate shortening axes. This kinematic evolution may be related to the counterclockwise rotation of the Adria plate since the Oligocene, possibly associated with the buoyant forces at the root of the belt, which induced an overall dextral-transtensive regime in the inner Western Alps, as already proposed by some authors (Sue and Tricart 2003, Sue et al. 2007a). Seismological and geodetic data suggest that this rotation is still ongoing (Nocquet and Calais 2003; Delacou et al. 2004) 
even if with low deformation rates. Nevertheless, the debate about the geodynamic processes that drove the exhumation of the Western Alps remains still lively.

The post-collisional tectonic evolution of the Northern Cottian Alps, described in this study, is different from that proposed in the adjacent areas of the Piemonte Zone (Ballèvre et al. 1990; Tricart et al. 2004; Schwartz et al. 2008), where a protracted extensional regime since Eocene times has been showed. These new data raise some questions about the exhumation mechanisms of the Dora-Maira Unit (Philippot 1990) at shallow crustal levels, at least in its northern part, as also was pointed out by Tricart et al. (2007) on the basis of the ages of the apatite fission tracks found in this sector.

It must be outlined, however, that caution may be used in the tectonic reconstruction in areas characterised by polyphasic tectonic evolution, like that analysed here, as some regional fault systems show different and, sometimes, contrasting types of movement, still difficult to constrain with available data. Future research concerning detailed field mapping and analysis of post-metamorphic structural associations in the innermost sectors of the Western Alps will improve our knowledge of the postcollisional tectonics and subsequently the mechanisms that drove the last stages of the exhumation of the tectonic units cropping out in this sector.

\section{References}

Agard P, Fournier M, Lacombe O (2003) Post-nappe extension in the inner Western Alps (LiguroPiemontese Schistes Lustrés): continuity with late ductile exhumation. Terra Nova 15:306-314

Allmendinger RW, Charlesworth HAK, Earslev EA, Guth P, Langenberg CW, Pecher A, Whalley JS (1991) Microcomputer software for structural geologists. J Struct Geol 13:1079-1083

Angelier J (1994) Palaeostress analysis of small-scale brittle structures. In: Hancock P (ed) Continental deformation. Pergamon Press, Oxford, pp 53-100

Baietto A, Perello P, Cadoppi P, Martinotti G (2009) Alpine tectonic evolution and thermal water circulations of the Argentera Massif (South-Western Alps). Swiss J Geosci 102:223-245

Balestrieri ML, Bigazzi G, Cadoppi P, Sacchi R (2004) Studio preliminare di alcuni campioni di ortoderivati provenienti dalla Val di Susa mediante il metodo delle tracce di fissione su apatite. In: Sacchi R, Balestro G, Cadoppi P, Carraro F, Delle Piane L, Di Martino L, Enrietti M, Gallarà F, Gattiglio M, Martinotti G, Perello P (eds) Studi geologici in Val di Susa finalizzati ad un nuovo collegamento ferroviario Torino-Lione. Museo Regionale Di Scienze Naturali (Torino), monograph series, 41, pp 103-115

Balestro G, Cadoppi P, Tallone S (2007) Evoluzione strutturale nella bassa valle di Susa e Sangone: la Zona di Deformazione Col del Lis-Trana. Rend Soc Geol It nuova serie 5:276-277

Balestro G, Cadoppi P, Perrone G, Tallone S (2009a) Tectonic evolution along the Col del Lis-Trana deformation zone (Internal Western Alps). Ital J Geosci 128:331-339

Balestro G, Cadoppi P, Fioraso G, Polino R, Tallone S (2009b) Torino Ovest-155 sheet, Geological Map of Italy, 1:50.000 scale. APAT, Rome, Italy. http://www.apat.gov.it/Media/carg/Rilevamenti_Def/155_ TORINOOVEST/155.htm 
Ballèvre M, Lagabrielle Y, Merle O (1990) Tertiary ductile normal faulting as a consequence of lithospheric stacking in the western alps. In: Roure F, Heitzmann P, Polino R (eds) Deep structure of the Alps, Mém Soc Géol France, 19, pp 1309-1318

Bernet M, Zattin M, Garver I, Brandon MT, Vance J (2001) Steady-state exhumation of the European Alps. Geology 29:35-38

Béthoux N, Sue C, Paul A, Virieux J, Fréchet J, Thouvenot F, Cattaneo M (2007) Local tomography and focal mechanisms in the south-western Alps: comparison of methods and tectonic implications. Tectonophysics 432:1-19

Bigi G, Castellarin A, Coli M, Dal Piaz GV, Sartori R, Scandone P, Vai GB (1990) Structural model of Italy, Sheet n.1 C.N.R., Progetto Finalizzato Geodinamica, Selca Firenze

Bistacchi A, Massironi M (2000) Post-nappe brittle tectonics and kinematic evolution of the north-western Alps: an integrated approach. Tectonophysics 327:267-292

Bistacchi A, Massironi M, Eva E, Solarino S (2000) Miocene to present kinematics of the NW-Alps: evidence from remote sensing, structural analysis, seismotectonics and thermocronology. J Geodyn 30:205-228

Brix MR, Stöckhert B, Seidel E, Theye T, Thomson SN, Küster M (2002) Thermobarometric data from a fossil zircon partial annealing zone in high pressure-low temperature rocks of eastern and central Crete, Greece. Tectonophysics 349:309-326

Bussy F, Cadoppi P (1996) U-Pb zircon dating of granitoids from the Dora-Maira Massif (Western Italian Alps). Schweiz Miner Petrogr Mitt 76:217-233

Butler RWH, Matthews SJ, Parish M (1986) The NW external Alpine thrust belt and its implications for the geometry of the western Alpine orogen. In: Coward MP, Ries AC (eds) Collision Tectonics. Geological Society, London, Special Publications, 19, pp 245-260

Cadoppi P, Tallone S (1992) Structural and lithostratigraphic heterogeneity of the northern part of DoraMaira Massif (Western Alps). Atti Tic Sci Terra 35:9-18

Cadoppi P, Balestrieri ML, Bigazzi G, Riccio I, Tallone S (2002a) Oligocene-Miocene differential exhumation of the internal Western Alps in the lower-middle Susa Valley: evidence from apatite fission-track analysis. Abstracts of the 81th Congress of the Italian Geological Society, Turin 10-12 Sept 2002, pp 73-74

Cadoppi P, Castelletto M, Sacchi R, Baggio P, Carraro F, Giraud V (2002b) Note illustrative della Carta Geologica d'Italia, scale 1:50.000, Susa-154 Sheet. APAT, Rome, Italy

Cadoppi P, Giardino M, Perrone G, Tallone S (2007) Litho-structural control, morphotectonics and deepseated gravitational deformations in the evolution of the alpine relief: a case study in the Lower Susa Valley (Italian Western Alps). Quat Int 171-172:143-160

Calais E, Nocquet JM, Jouanne F, Tardy M (2002) Current strain regime in the Western Alps from continuous Global Positioning System measurements, 1996-2001. Geology 30:651-654

Cannic S, JI Mugnier, Lardeaux JM (1999) Neogene extension in the western Alps. Mem Sci Geol (Padova) 51:33-45 
Carraro F, Cadoppi P, Baggio P, Bellino L, Castelletto M, Giraud V, Mensio L (2002) Susa -154 sheet, Geological Map of Italy, 1:50.000 scale. APAT, Rome, Italy

Castellarin A (2001) Alps-Apennines and Po Plain-Frontal Apennines relations. In: Vai GB, Martini P (eds) Anatomy of an Orogen: the Apennines and adjacent Mediterranean Basins. Kluwer, Great Britain, pp 177196

Ceriani S, Schmid SM (2004) From N-S collision to WNW-directed post-collisional thrusting and folding: structural study of the Frontal Penninic Units in Savoie (Western Alps, France). Eclogae Geol Helvet 97:347369

Champagnac JD, Sue C, Delacou B, Burkhard M (2004) Brittle deformation in the inner northwestern Alps: from early orogen-parallel extrusion to late orogen-perpendicular collapse. Terra Nova 16:232-242

Champagnac JD, Sue C, Delacou B, Tricart P, Allanic C, Burkhard M (2006) Miocene orogen-parallel extension in the inner Western Alps revealed by dynamical fault analyses. Tectonics 25:TC3014. doi:10. 1029/2004TC001779

Claypool AL, Klepeis KA, Dockrill B, Clarke G, Zwingmann H, Tulloch A (2002) Structures and kinematics of oblique continental convergence in Northern Fiordland, New Zealand. Tectonophysics 359:329-358

Collombet M, Thomas JC, Chauvin A, Tricart P, Bouillin JP, Gratier JP (2002) Counterclockwise rotation of the Western Alps since the Oligocene: new insights from paleomagnetic data. Tectonics 21:278-293

Coward MP, Dietrich D (1989) Alpine tectonics-an overview. In: Coward MP, Dietrich D, Park RG (eds) Alpine tectonics. Geological Society, London, Special Publications, 45, pp 1-29

Debelmas J (1986) Intracontinental subduction and mountain uplift: the example of Western Alps. Géologie Alpine 62:1-10

Dehandschutter B (2001) Study of the recent structural evolution of continental basins in Altai-Sayan (Central Asia). Phd Thesis, University of Bruxelles

Delacou B, Sue C, Champagnac JD, Burkhard M (2004) Present-day geodynamics in the bend of the western and central Alps as constrained by earthquake analysis. Geophys J Int 158:753-774

Delacou B, Sue C, Nocquet JM, Champagnac JD, Allanic C, Burkhard M (2008) Quantification of strain rate in the Western Alps using geodesy: comparisons with seismotectonics. Swiss J Geosci 101:377-385

Depaola N, Holdsworth RE, McCaffrey KJW, Barchi MR (2005) Partitioned transtension: an alternative to basin inversion models. J Struct Geol 27:605-625

Dupin JM, Sassi W, Angelier J (1993) Homogeneous stress hypothesis and actual fault slip: a distinct element analysis. J Struct Geol 15:1033-1043

Elter FM, Piccardo GB, Polino R, Zanetti A, Spagnolo G, Poggi E, Balbi P (2005) Structural and compositional features of the Mt. Musine peridotites (Lanzo Massif, western Alps, Italy). Ofioliti 30:161-173

Eva E, Solarino S, Eva C, Neri G (1997) Stress tensor orientation derived from fault plane solution in the Southwestern Alps. J Geophys Res 102:8171-8185 
Flodin EA, Aydin A (2004) Evolution of a strike-slip fault network, Valley of Fire State Park, southern Nevada. Geol Soc Am Bull 116:42-59

Gamond JF (1987) Bridge structures as sense of displacement criteria in brittle fault zones. J Struct Geol 9:609-620

Gapais D, Cobbold PR, Bourgeois O, Rouby D, de Urreiztieta M (2000) Tectonic significance of fault-slip data. J Struct Geol 22:881-888

Giardino M, Polino R (1997) Le deformazioni di versante dell'alta valle di Susa: risposta pellicolare dell'evoluzione tettonica recente. II Quaternario 10:293-298

Gourlay P, Ricou LE (1983) Le décrochement dextre tardif de la structure de Chamonix (Alpes françaises et suisses). C R Acad Sci Paris 296:927-932

Harris LB, Cobbold PR (1984) Development of conjugate shear bands during bulk simple shearing. J Struct Geol 7:37-44

Hobbs BE, Means WD, Williams PF (1976) An outline of structural geology. Wiley, New York

Hu JC, Angelier J (2004) Stress permutations: three-dimensional distinct element analysis accounts for a common phenomenon in brittle tectonics. J Geophys Res 109:B09403. doi:10.1029/2003JB002616

Hubbard M, Mancktelow NS (1992) Lateral displacement during Neogene convergence in the Western and Central Alps. Geology 20:943-946

Kastrup U, Zoback ML, Deichmann N, Evans K, Giardini D (2004) Stress field variations in the Swiss Alps and the northern Alpine foreland derived from inversion of fault plane solutions. J Geophys Res 109:B01402. doi:10.1029/2003JB002550

Kelly PG, Sanderson DJ, Peackock DCP (1998) Linkage and evolution of conjugate strike-slip fault zones in limestones of Somerset and Northumbria. J Struct Geol 20:1477-1493

Labaume P, Ritz JF, Philip H (1989) Failles normales récentes dans les Alpes sud-occidentales: leurs relations avec la tectonique compressive. C R Acad Sci Paris 308:1553-1560

Lanza R (1975) Profili magnetici e di gravità nelle Alpi Occidentali. Riv Ital Geof Sci Aff 2(2):175-183

Laubscher HP (1991) The arc of Western Alps today. Eclogae Geol Helvet 84:631-659

Lemoine M, Tricart P (1986) Les Schistes Lustrés des Alpes Occidentales: approche stratigraphique, structurale et sèdimentologique. Eclogae Geol Helvet 79:271-294

Malusà MG (2004) Post-metamorphic evolution of Western Alps: kinematic constraints from a multidisciplinary approach. Phd Thesis, University of Turin-CNR IGG, Turin, Italy, 336 pp

Malusà MG, Polino R, Zattin M, Bigazzi G, Martin S, Piana F (2005) Miocene to present differential exhumation in the Western Alps: insights from fission track thermocronology. Tectonics 24:TC3004. doi:10. 1029/2004TC001782

Malusà MG, Polino R, Zattin M (2009) Strain partitioning in the axial NW Alps since the Oligocene. Tectonics 28:TC 3005. doi:10.1029/2008TC002370 
Mancktelow N (1992) Neogene lateral extension during convergence in the Central Alps: evidence from interrelated faulting and backfolding around the Simplon Pass. Tectonophysics 215:295-317

Marrett R, Allmendinger RW (1990) Kinematic analysis of fault-slip data. J Struct Geol 12:973-986

Ménard G, Thouvenot $F$ (1984) Ecailage de la lithosphère européenne sous les Alpes occidentales: arguments gravimétriques et sismiques liés à l'anomalie d'Ivrea. Bull Soc Géol France 26:875-884

Mosca P, Polino R, Rogledi S, Rossi M (2009) New data for the kinematic interpretation of the AlpsApennines junction (Northwestern Italy). Int J Earth Sci. doi:10.1007/s00531-009-0428-2

Mugnier JL, Vialon P (1986) Deformation and displacement of the Jura cover on its basement. J Struct Geol 8:373-387

Nicolas A, Polino R, Hirn A, Nicolich R, Ecors-Crop Working Group (1990) ECORS-CROP traverse and deep structure of the Western Alps: a synthesis. Mém Soc Géol France 156:15-27

Nieto-Samaniego ÁF (1999) Stress, strain and fault patterns. J Struct Geol 21:1065-1070

Nocquet JM, Calais E (2003) Crustal velocity field of Western Europe from permanent GPS array solutions, 1996-2001. Geophys J Int 154:72-88

Perello P, Piana F, Martinotti G (1999) Neoalpine structural features at the boundary between the Penninic and Helvetic domains. Eclogae Geol Helvet 92:347-359

Perello P, Marini L, Martinotti G, Hunziker JC (2001) The thermal circuits of the Argentera Massif (western Alps, Italy): an example of low enthalpy geothermal resources controlled by Neogene alpine tectonics. Eclogae Geol Helvet 94:75-94

Perello P, Delle Piane L, Piana F, Morelli M, Damiano A, Venturini G et al (2004a) New constraints on late to post-Oligocene deformation history of the Western Alps: data from Middle Susa valley and High Maurienne valley. Abstract, 32nd I.G.C. - Firenze:247

Perello P, Delle Piane L, Piana F, Stella F, Damiano A (2004b) Brittle post-metamorphic tectonics in the Gran Paradiso Massif (North-Western Italian Alps). Geodinamica Acta 17:71-90

Perrone G (2006) Evoluzione tettonica post-metamorfica e recente del distretto sismico del Pinerolese. Phd Thesis, University of Turin, Turin-Italy, 205 pp, ISBN 88-902575-0-4

Perrone G, Morelli M, Cadoppi P, Tallone S, Giardino M (2009a) A multidisciplinary approach for the study of the fault network in the Northern sector of the Dora-Maira Unit (Western Alps). Ital J Geosci 128:541549

Perrone G, Eva E, Balestro G, Cadoppi P, Solarino S, Fioraso G, Tallone S (2009b). Seismotectonic investigations in the inner Cottian Alps: an integrated approach. 16th-19th November 2009. Abstract, 28th GNGTS Congress, Trieste, pp 114-116

Philippot P (1990) Opposite vergence of nappes and crustal extension in the French-Italian western Alps. Tectonics 9:1143-1164

Piana F (2000) Structural features of western Monferrato (Alps-Apennines junction zone, NW Italy). Tectonics 19:943-960 
Platt JP, Cunningham PC, Weston P, Lister GS, Peel F, Baudin T, Dondey H (1989) Thrusting and backthrusting in the Briançonnais domain of the western Alps. In: Coward MP, Dietrich D, Park RG (eds) Alpine tectonics, Geological Society, London, Special Publications, vol 45, pp 135-152

Pognante U (1980) Preliminary data on the Piemonte ophiolite nappe in lower Val Susa-Val Chisone area, Italian Western Alps. Ofioliti 5:21-240

Pognante U, Sandrone R (1989) Eclogites in the Northern Dora-Maira Nappe (Western Alps, Italy). Mineral Petrol 40:57-71

Polino R, Dal Piaz GV, Gosso G (1990) Tectonic erosion at the Adria margin and accretionary processes for the Cretaceous orogeny of the Alps. Mem Soc Geol France 156:345-367

Polino R, Dela Pierre F, Fioraso G, Giardino M, Gattiglio M (2002) Bardonecchia-132,152,153 sheet, Geological Map of Italy, 1:50.000 scale. APAT, Rome, Italy

Pollard DD, Saltzer SD, Rubin AM (1993) Stress inversion methods: are they based on faulty assumptions? J Struct Geol 15:1045-1054

Rahn M, Brandon M, Batt G, Garver J (2004) A zero-damage model for fission-track annealing in zircon. Am Miner 89:473-484

Reiners PW, Brandon MT (2006) Using thermochronology to understand orogenic erosion. Annu Rev Earth Planet Sci 34:419-466

Ricou LE, Siddans WB (1986) Collision tectonics in the western Alps. Geological Society, London, Special Publications, 19, pp 229-244

Rolland Y, Lardeaux J-M, Guillot S, Nicollet C (2000) Extension syn-convergence, poinçonnement vertical et unités métamorphiques contrastées en bordure ouest du Gran Paradis (Alpes Franco-Italiennes).

Geodynamica Acta 13:133-148

Rossetti F, Storti F, Läufer A (2002) Brittle architecture of the Lanterman Fault and its impact on the final terrane assembly in North Victoria Land, Antarctica. J Geol Soc Lond 159:159-173

Roure F, Polino R, Nicolich R (1990) Early Neogene deformation beneath the Po Plain: constraints on the post-collisional Alpine evolution. Mém Soc Géol France 156:309-322

Sacchi R, Balestro G, Cadoppi P, Carraro F, Delle Piane L, Di Martino L, Enrietti M, Gallarà F, Gattiglio M, Martinotti G, Perello P (2004) Studi geologici in Val di Susa finalizzati ad un nuovo collegamento ferroviario Torino-Lione. Museo Regionale di Scienze Naturali (Torino), monograph series, 41, 115 pp

Sanderson DJ, Marchini WRD (1984) Transpression. J Struct Geol 6:449-458

Sandrone R, Cadoppi P, Sacchi R, Vialon P (1993) The Dora-Maira Massif. In: Von Raumer JF, Neubauer F (eds) Pre-Mesozoic geology in the Alps. Springer, Berlin, pp 317-325

Schmid SM, Kissling E (2000) The Arc of Western Alps in the light of geophysical data on deep crustal structure. Tectonics 19:62-85

Schmid SM, Zingg A, Handy M (1987) The kinematics of movements along the Insubric Line and the emplacement of the Ivrea Zone. Tectonophysics 135:47-66 
Schmid SM, Aebli HR, Heller F, Zingg A (1989) The role of the Periadriatic Line in the tectonic evolution of the Alps. In: Alpine Tectonics, Coward MP, Dietrich D, Park RG (eds) Geological Society, London, Special Publications, 45, pp 153-171

Schmid SM, Fügenschuh B, Kissling E, Schuster R (2004) Tectonic map and overall architecture of the alpine orogen. Eclogae Geol Helvet 97:93-117

Scholz CH (1988) The brittle-plastic transition and the depth of seismic faulting. Geol Rundsch 77:319-328

Schwartz S, Tricart P, Lardeaux JM, Guillot S, Vidal O (2008) Late tectonic and metamorphic evolution of the Piedmont accretionary wedge (Queyras Schistes lustrés, western Alps): Evidences for tilting during Alpine collision. Geol Soc America Bull. doi:10.1130/B26223.1

Selverstone J (2005) Are the Alps collapsing? Annu Rev Earth Planet Sci 33:113-132

Seward D, Mancktelow NS (1994) Neogene kinematics of the central and western Alps: evidence from fission-track dating. Geology 22:803-806

Sibson RH (1977) Fault rocks and fault mechanisms. J Geol Soc Lond 133:191-213

Steck A, Hunziker J (1994) The tertiary structural and thermal evolution of the Central Alps: compressional and extensional structures in an orogenic belt. Tectonophysics 238:229-254

Sue C, Tricart P (1999) Late Alpine brittle extension above the Frontal Pennine Thrust near Briançon, Western Alps. Eclogae Geol Helvet 92:171-181

Sue C, Tricart P (2002) Widespread post-nappe normal faulting in the Internal Western Alps: a new constraint on arc dynamics. J Geol Soc Lond 159:61-70

Sue C, Tricart P (2003) Neogene to ongoing normal faulting in the inner western Alps: a major evolution of the late alpine tectonics. Tectonics 22(5):1050. doi:10.1029/2002TC001426.2003

Sue C, Thouvenot F, Frechét J, Tricart P (1999) Widespread extension in the core of the western Alps revealed by earthquake analysis. J Geoph Res 104:25611-25622

Sue C, Delacou B, Champagnac JD, Allanic C, Tricart P, Burkhard M (2007a) Extensional neotectonics around the bend of the Western/Central Alps: an overview. Int J Earth Sci 96:1101-1129

Sue C, Delacou B, Champagnac JD, Allanic C, Burkhard M (2007b) Aseismic deformation in the Alps: GPS vs. seismic strain quantification. Terra Nova 19:182-188

Tallone S, Cadoppi P, Balestro G, Delle Piane L, Perello P, Riccio I (2002) Ductile-to-brittle tectonic evolution at the structural knot between the Lower and Middle Susa Valley (Province of Turin). Abstracts of the 81th Congress of the Italian Geological Society, Turin 10-12 Sept 2002, pp 310-311

Tricart P (1984) From passive margin to continental collision: a tectonic scenario for the western Alps. Am J Sci 284:97-120

Tricart P (2004) From extension to transpression during the final exhumation of the Pelvoux and Argentera massifs, Western Alps. Eclogae Geol Helvet 97:429-439 
Tricart P, Sue C (2006) Faulted backfold versus reactivated backthrust: the role of inherited structures during late extension in the frontal Piémont nappes east of Pelvoux (Western Alps). Int J Earth Sci 95:827840

Tricart P, Schwartz S, Sue C, Poupeau G, Lardeaux JM (2001) La dénudation tectonique de la zone ultradauphinoise et l'inversion du front briançonnais au sud-est du Pelvoux (Alpes occidentales): Une dynamique Miocène à actuelle. Bull Soc Géol France 172:49-58

Tricart P, Schwartz S, Sue C, Lardeaux JM (2004) Evidence of synextension tilting and doming during final exhumation from analysis of multistage faults (Queyras Schistes lustrés, Western Alps). J Struct Geol 26:1633-1645

Tricart P, Van der Beek P, Schwartz S, Labrin E (2007) Diachronous late-stage exhumation across the western Alpine arc: constraints from apatite fission-track termochronology between Pelvoux and DoraMaira Massifs. J Geol Soc London 164:163-174

Twiss RJ, Unruh JR (1998) Analysis of fault-slip inversions: do they constrain stress or strain rate? J Geophys Res 103:12205-12222

Vanossi M, Perotti C, Seno S (1994) The Maritime Alps arc in the Ligurian and Tyrrhenian systems.

Tectonophysics 230:75-89

Vigny C, Chery J, Duquesnoy T et al (2002) GPS network monitor the western Alps' deformation over a five year period: 1993-1998. J Geodesy 76:63-76 